\title{
Evolution of continental temperature seasonality from the Eocene greenhouse to the Oligocene icehouse - A model-data comparison
}

Agathe Toumoulin ${ }^{1}$, Delphine Tardif ${ }^{1,2}$, Yannick Donnadieu ${ }^{1}$, Alexis Licht ${ }^{1}$, Jean-Baptiste Ladant $^{3}$, Lutz Kunzmann ${ }^{4}$, Guillaume Dupont-Nivet ${ }^{5,6}$

$5 \quad{ }^{1}$ Aix Marseille Université, CNRS, IRD, INRA, Collège de France, CEREGE, 13545 Aix-en-Provence, France

${ }^{2}$ Université de Paris, Institut de physique du globe de Paris, CNRS, F-75005 Paris, France

${ }^{3}$ Laboratoire des Sciences du Climat et de l'Environnement, LSCE/IPSL, CEA-CNRS-UVSQ, Université Paris-Saclay, 91191 Gif-sur-Yvette, France

${ }^{4}$ Senckenberg Natural History Collections Dresden, Königsbrücker Landstraße 159, 01109 Dresden, Germany

$10 \quad{ }^{5}$ Géosciences Rennes, UMR CNRS 6118, Univ Rennes, 35042 Rennes, France

${ }^{6}$ Institute of Geosciences, Potsdam University, 14469 Potsdam, Germany

Correspondence to: Agathe Toumoulin (agathe.toumoulin@gmail.com)

Abstract. At the junction of greenhouse and icehouse climate phases, the Eocene-Oligocene Transition (EOT) is a key moment in the history of the Cenozoic climate. Yet, while it is associated with severe extinctions and biodiversity turnovers,

15 terrestrial climate evolution remains poorly resolved. Paleobotanical and geochemical continental records suggest a marked cooling in winter, leading to the development of more pronounced seasons (i.e., increase of the Mean Annual Range of Temperature, MATR) in parts of the Northern Hemisphere. However, this increase of the annual temperature range has been poorly studied by climate models; uncertainties remain about the geographical extent of this phenomenon and the associated climatic processes. Although other components of the climate system vary seasonally (e.g., precipitation, wind), we therefore

20 focus on the seasonality of temperatures only.

In order to better understand and describe temperature seasonality patterns from the middle Eocene to the early Oligocene, we use the Earth System Model IPSL-CM5A2 and a set of simulations reconstructing the EOT through three major climate forcings: pCO2 decrease (1120/840 to $560 \mathrm{ppm})$, the Antarctic ice-sheet (AIS) formation, and the associated sea-level decrease $(-70 \mathrm{~m})$.

25 Our simulations suggest that seasonality changes across the EOT rely on the combined effects of the different tested mechanisms which result in zonal to regional climate responses. Broad continental areas of increased MATR reflect a strengthening of seasonality (from $4^{\circ} \mathrm{C}$ to $>10^{\circ} \mathrm{C}$ increase of the MATR) across the EOT in agreement with MATR and Coldest Month Mean Temperatures (CMMT) changes indicated by a review of existing proxies. pCO2 decrease induces a zonal pattern with alternating increasing and decreasing seasonality bands. In the northern high-latitudes, it results in sea-ice and surface albedo feedback, driving a strong increase in seasonality (up to $8^{\circ} \mathrm{C}$ MATR increase). Conversely, the onset of the AIS is responsible for a more constant surface albedo, which leads to a strong decrease in seasonality in the southern mid- to high-latitudes $\left(>40^{\circ} \mathrm{S}\right)$. Finally, continental areas emerged due to the sea level lowering cause the largest increase in 
seasonality and explain most of the global heterogeneity in MATR changes ( $\triangle$ MATR) patterns. $\triangle$ MATR patterns we reconstruct are consistent with the variability of the EOT biotic crisis intensity across the Northern Hemisphere.

\section{Introduction}

\subsection{Context}

The Eocene-Oligocene transition is one of the major climatic events of the last 66 million years. Perceived as the hinge between a greenhouse ancient world and the present icehouse world, it has been extensively studied and described from both marine and terrestrial environments (e.g. Katz et al., 2008; Mosbrugger et al., 2005; Zachos et al., 2001; Zanazzi et al.,

40 2007). This climate change is characterized by different phases: a progressive step between 50 and $33.9 \mathrm{Ma}$, and an abrupt cooling acceleration during the Eocene Oligocene Transition (EOT, ca. $33.9 \mathrm{Ma}$ ), enabling the onset of the antarctic icesheet (AIS; Lear et al., 2008; Zachos et al., 2001). Some paleobotanical and geochemical studies suggest that the decrease in continental temperatures was particularly marked during winter months, which led to higher seasonal temperature contrast (e.g. Eldrett et al., 2011; Mosbrugger et al., 2005; Utescher et al., 2015; Zanazzi et al., 2015). Understanding these seasonal

45 changes between the Eocene and the Oligocene is important since EOT is associated with major extinction events: the "Grande Coupure" in Europe and the "Mongolian Remodelling" in central Asia (Meng and McKenna, 1998; Stehlin, 1909; see Coxall and Pearson, 2007 for review). EOT vegetation response is heterogeneous across continents but shows important composition turnovers in some areas, notably where faunal turnover is important (e.g. Barbolini et al., 2020; Eldrett et al., 2009; Hutchinson et al., 2021; Pound and Salzmann, 2017).

50 Temperature seasonality can be quantified by the Mean Annual Temperature Range (MATR), which consists in the temperature difference between the warmest and coldest months of the year. Increasing MATR can be done through increased summer temperatures, lowered winter temperatures, or both. MATR can be directly calculated from temperature proxies providing an estimation of the lowest and highest temperatures within a year, such as with the Climate Leaf Analysis Multivariate Program (CLAMP), which reconstructs temperatures from the modern correlation between climate

55 variables and leaf physiognomy (Wolfe, 1993; Yang et al., 2011), and the Coexistence Approach (CA), which uses modern relatives of fossil species to define a mutual climate range of environmental characteristics (Grimm and Potts, 2016; Mosbrugger and Utescher, 1997; Utescher et al., 2014). MATR can also be deduced from the variability of the temperature signal in geochemical proxies for temperatures, stable oxygen isotopes $(\delta 180)$, as the time resolution of the proxy does rarely allow for the direct reconstruction of seasonal temperatures (e.g. Ivany et al., 2000; Wade et al., 2012).

\section{$60 \quad 1.2$ Evolution of temperature seasonality}

The spatial distribution of temperature seasonality changes across the EOT is heterogeneous (e.g. Pound and Salzmann, 2017). Most changes are described in the Northern Hemisphere from paleobotanical reconstructions, and converge towards a greater seasonality in the early Oligocene than in the mid- to late Eocene. In North America, Western and central Europe, 
seasonality increase is recorded in the decline of species characteristic of warm paratropical to temperate environments such as conifers Doliostrobus sp. (conifers), Nypa sp. (Palms), Rhodomyrtophyllum sp. (Myrtaceae), and some families with tropical elements such as Annonaceae, Lauraceae, Cornaceae, Flacourtiaceae, Icacinaceae, Menispermaceae, and, depending on bioclimatic zones, the expansion of temperate to boreal vegetation through the increase of deciduous and / or coniferous species (Eldrett et al., 2009; Kunzmann et al., 2016; Kvaček, 2010; Kvaček et al., 2014; Mosbrugger et al., 2005; Utescher et al., 2015; Wolfe, 1992). These vegetation changes are associated with a decrease of the Coldest Month Mean Temperatures (CMMT) across the EOT $\left(-2.2\right.$ to $\left.-10.3^{\circ} \mathrm{C}\right)$ and starting earlier at some localities, during the mid- to late Eocene (Eldrett et al., 2009; Moraweck et al., 2019; Mosbrugger et al., 2005; Tanrattana et al., 2020; Tosal et al., 2019; Utescher et al., 2015; Wolfe, 1994). Isotopic analyses have also documented this seasonality increase in different continental localities between the Priabonian (37.8 to 33.9 Ma) and the Rupelian (33.9 to $27.82 \mathrm{Ma}$; Grimes et al., 2005; Hren et al., 2013; Zanazzi et al., 2015). Some of these changes are not directly quantifiable (e.g. the reduction of gastropods growing season length, United 75 Kingdom; Hren et al., 2013), others are particularly strong, with MATR increase up to $15.6^{\circ} \mathrm{C}$ (Canada; Zanazzi et al., 2015). Seasonality increase is also documented for shallow waters of the Gulf of Mexico (increase of the MATR; Ivany et al., 2000; Wade et al., 2012). Seasonality strengthening and associated vegetation changes have been proposed as driving factors for dental morphological changes for European grazing perissodactyls (Joomun et al., 2010). Some studies have suggested a link between increased temperature seasonality and latitude (e.g. Eldrett et al., 2009; Zanazzi et al., 2007, 2015)

80 but data seem insufficient to validate this relationship and this trend has not been confirmed by recent palynological compilation (Pound and Salzmann, 2017).

Southeast Europe and Anatolia show generally weaker and heterogeneous changes in temperature seasonality, with either no seasonality changes, slight seasonality lowering or slight seasonality strengthening from the mid Eocene to the Rupelian (Bozukov et al., 2009; Kayseri-Özer, 2013). This variable signal has been linked to a strong marine influence on this insular 85 part of Eocene Europe (Kayseri-Özer, 2013). Conversely, North and East Asia temperature seasonality evolution is more comparable to western Europe and North America trends (Quan et al., 2012; Utescher et al., 2015). Vegetation changes reflect an increase of the seasonal temperature range, mainly through the EOT (MATR increase of 2 to $2.5^{\circ} \mathrm{C}$; $\mathrm{CMMT}$ decrease of $\sim 2.2^{\circ} \mathrm{C}$ (Quan et al., 2012; Utescher et al., 2015). The appearance of tubers in lotus (Nelumbo sp.) during the Eocene suggests the establishment of a dormant phase in these plants and thus, of a period unfavorable to plant growth (Li et 90 al., 2014). Fossils showing these structures have been described in Southern China (Hainan Province) and in the extreme East of Russia (Kamchatka Peninsula); they could be favored by Eocene cooling and increased seasonality on the East Asian continent (Budantsev, 1997).

In the Southern Hemisphere, studies of Paleogene localities are rarer. Despite a record of late Eocene cooling in Australia, New Zealand and Patagonia, independent proxies (stable isotopes on teeth, bones and pedogenic carbonates, paleobotanical 95 reconstructions) do not suggest a marked temperature seasonality during the Eocene (Kohn et al., 2015; Nott and Owen, 1992; Pocknall, 1989). In Australia, the presence of more pronounced wood rings suggests a late Paleogene increase in 
seasonality starting in the mid-Oligocene at the earliest (Bishop and Bamber, 1985; Nott and Owen, 1992). Finally, the environmental and climatic impact of the EOT in Africa remains virtually undocumented (Hutchinson et al., 2021).

\subsection{Former model work}

100 A first attempt to explain temperature seasonality change was made by Eldrett et al. (2009). In their palynological and modelling study, Eldrett and coauthors explained high latitude (Greenland) seasonality strengthening by $p \mathrm{CO}_{2}$ drop and the consequent increase of sea-ice formation over the Arctic Ocean. Sea-ice extension induces a strong albedo feedback in their experiment, which results in a large decrease of atmospheric temperature during the winter. In addition, Li et al. (2018) showed an important contribution of geography changes to seasonality strengthening during the Oligocene. Apart from these

105 two studies, EOT modelling experiments mostly focused on oceans through mean annual temperature changes (Baatsen et al., 2020; Goldner et al., 2014; Hutchinson et al., 2018, see 2020; Kennedy et al., 2015; Kennedy-Asser et al., 2019, 2020; Ladant et al., 2014b). The recent model intercomparison of Hutchinson et al. (2021) has shown a reasonable agreement between $4 \mathrm{X}$ to $2 \mathrm{X}$ modelling experiments and proxy-data atmospheric and surface ocean temperature reconstructions. The different simulations of the model intercomparison support once more the primary role of $p \mathrm{CO}_{2}$ drop. Hutchinson et al.

110 (2021), also quantified the general effect of AIS formation and contemporary paleogeographic changes (opening of Southern Ocean gateways, Antarctic geography or global geography). EOT modelling experiments yield mixed answers regarding the temperature feedback resulting from both AIS and paleogeographic changes (Goldner et al., 2014; Kennedy et al., 2015; Ladant et al., 2014a, 2014b). Among these models, only one tested the combined effect of both AIS and global paleogeographic changes (Kennedy et al., 2015) and suggested a moderate impact of AIS on global climate sensitivity, as

115 previously suggested by other modelling work (Goldner et al., 2013; Kennedy et al., 2015).

\subsection{Aim of the study}

This study is an attempt to reconstruct temperature seasonality changes described by paleoenvironmental and paleoclimatic data between the middle Eocene and the early Oligocene. It includes both a synthesis of indicators of seasonality changes (Table S1) and paleoclimatic modelling. We reconstruct global patterns of temperature seasonality change and their main 120 mechanisms through a set of five simulations taking into account the three-major climate forcings described through this time interval: $p \mathrm{CO}_{2}$ drawdown, AIS formation and concomitant sea-level lowering.

\section{Material and methods}

We used the IPSL-CM5A2 general circulation model, which is built upon the CMIP5 Earth system model developed at the Institut Pierre-Simon Laplace (IPSL), IPSL-CM5A-LR (Dufresne et al., 2013, Sepulchre et al., 2019). The IPSL-CM5A-LR

125 Earth system model is composed of the LMDZ atmospheric model (Hourdin et al., 2013), the ORCHIDEE land surface and vegetation model (Krinner et al., 2005), and the NEMO v3.6 ocean model which includes modules for ocean dynamics 
(OPA8.2, Madec, 2008), biochemistry (PISCES, Aumont et al. 2015) and sea-ice (LIM2, Fichefet and Morales-Maqueda, 1997). The atmospheric grid has a horizontal resolution of $3.75^{\circ}$ longitude per $1.875^{\circ}$ latitude $(96 \times 95$ grid points), and is divided into 39 vertical levels. For a more detailed description of the model and its different components, the reader is referred to Sepulchre et al. (2020).

Five simulations were carried out to reconstruct the evolution of temperature seasonality from the middle Eocene to the early Oligocene (Table 1). The applied 40 Ma paleogeography framework is the map developed by Poblete et al. (2021) and already used in Tardif et al. (2020) and Toumoulin et al. (2020). It features common late Eocene geography characteristics such as: an open Panama Seaway, an open Tethys with submerged Arabic peninsula, a strongly maritime Europe, a Turgai

Strait between Europe and Asia, and a narrow Southern Ocean gateways (Figure 1). The orbital parameters were set to preindustrial values and the solar constant was reduced accordingly to its Eocene value $\left(1360.19 \mathrm{~W} / \mathrm{m}^{2}\right.$; Gough, 1981). Vegetation was implemented as a boundary condition, using a zonal band of PFTs using modern vegetation distribution patterns.

\begin{tabular}{|l|l|l|l|l|l|}
\hline Simulation & $\boldsymbol{p} \mathbf{C O}_{2}$ & AIS & \% Land $\left(\mathbf{M k m}^{2}\right)$ & MAT $\left({ }^{\circ} \mathbf{C}\right)$ & SST $\left({ }^{\circ} \mathbf{C}\right)$ \\
\hline $4 X$ & $1120 \mathrm{ppm}$ & $/$ & 132.3 & 26.4 & 28.2 \\
\hline $\mathbf{3 X} *$ & $\mathbf{8 4 0} \mathbf{~ p p m}$ & $/$ & $\mathbf{1 3 2 . 3}$ & $\mathbf{2 3 . 7}$ & $\mathbf{2 5 . 9}$ \\
\hline $2 \mathrm{X}$ & $560 \mathrm{ppm}$ & $/$ & 132.3 & 20.6 & 23.2 \\
\hline $2 X-I C E$ & $560 \mathrm{ppm}$ & $32.510^{6} \mathrm{~km}^{3}$ & 132.3 & 19.7 & 22.9 \\
\hline 2X-ICE-SL & $\mathbf{5 6 0} \mathbf{~ p p m}$ & $\mathbf{3 2 . 5} \mathbf{1 0}^{\mathbf{6}} \mathbf{k m}^{\mathbf{3}}$ & $\mathbf{1 5 2 . 7}$ & $\mathbf{1 8 . 7}$ & $\mathbf{2 2 . 2}$ \\
\hline
\end{tabular}

Table 1: Experimental design. Abbreviations: AIS: Antarctic Ice-Sheet volume (Ladant et al., 2014b); \% Land: total land surface (millions of $\mathrm{km}^{2}: 10^{6} \mathrm{~km}^{2}$ ); MAT: Mean Annual global 2-meter air Temperature $\left({ }^{\circ} \mathrm{C}\right.$ ); SST: Sea Surface Temperatures $\left({ }^{\circ} \mathrm{C}\right)$. Simulations with an asterisk constitute realistic middle Eocene (Lutetian / Bartonian) and early Oligocene (Rupelian) scenarios, others are either sensitivity experiments $(2 \mathrm{X}, 2 \mathrm{X}-\mathrm{ICE})$ or use the high value of the pCO range estimated for the time interval $(4 \mathrm{X})$.

Simulations were compared in pairs to highlight differences between the late Eocene and the early Oligocene. The simulation set is composed of both realistic and idealized experiments (Table 1). Simulations $4 \mathrm{X}, 3 \mathrm{X}$ and $2 \mathrm{X}$ represent most of the $\mathrm{CCO}_{2}$ range described from the mid-Eocene (Lutetian) to the early Oligocene (Rupelian; Foster et al., 2017). These $p \mathrm{CO}_{2}$ values enable the description of the $\mathrm{CO}_{2}$ reduction effect on climate through this time interval and have been used in most former modelling experiments on the EOT (Hutchinson et al., 2021). Simulations $4 \mathrm{X}$ and $3 \mathrm{X}$ cover the range of potential climate values prior to the EOT (Lutetian to Priabonian). The idealized simulation $2 \mathrm{X}$ allows the identification of a 1 to 2 PAL $p \mathrm{CO}_{2}$ lowering alone. In a complementary way, simulations $2 \mathrm{X}$-ICE and $2 \mathrm{X}$-ICE-SL describe the early Oligocene climate, following the Antarctic Ice-sheet formation. Both simulations are parameterized in the same way outside 
sea level, which is $70 \mathrm{~m}$ lower in 2X-ICE-SL. The use of 2X-ICE provides a theoretical description of the effect of an icecovered Antarctica on climate, while 2X-ICE-SL constitutes a realistic representation of the early Oligocene climate. In these experiments, the Antarctic ice cap was set to $32.5 .10^{6} \mathrm{~km}^{3}$ according to Ladant et al. (2014b). The 70-m sea-level drop was defined following eustatic drop estimates for the EOT (Coxall et al., 2005; Katz et al., 2008; Lear et al., 2008). It is responsible for important geography changes related to an increase of land proportion, such as the emergence of the Arabic

160 Peninsula and the retreat of the proto-Paratethys epicontinental sea.

All simulations are run for 4000 years when temperatures indicate a quasi-equilibrium with only negligible temperature drifts within the global mean ocean $\left(<0.1^{\circ} \mathrm{C} /\right.$ century; Figure S1). These trends are consistent with most model studies and do not affect the quality of atmospheric change described in this study (e.g. Hutchinson et al., 2018; Lunt et al., 2016). The results considered here are averages of the last 100 years of the model runs.
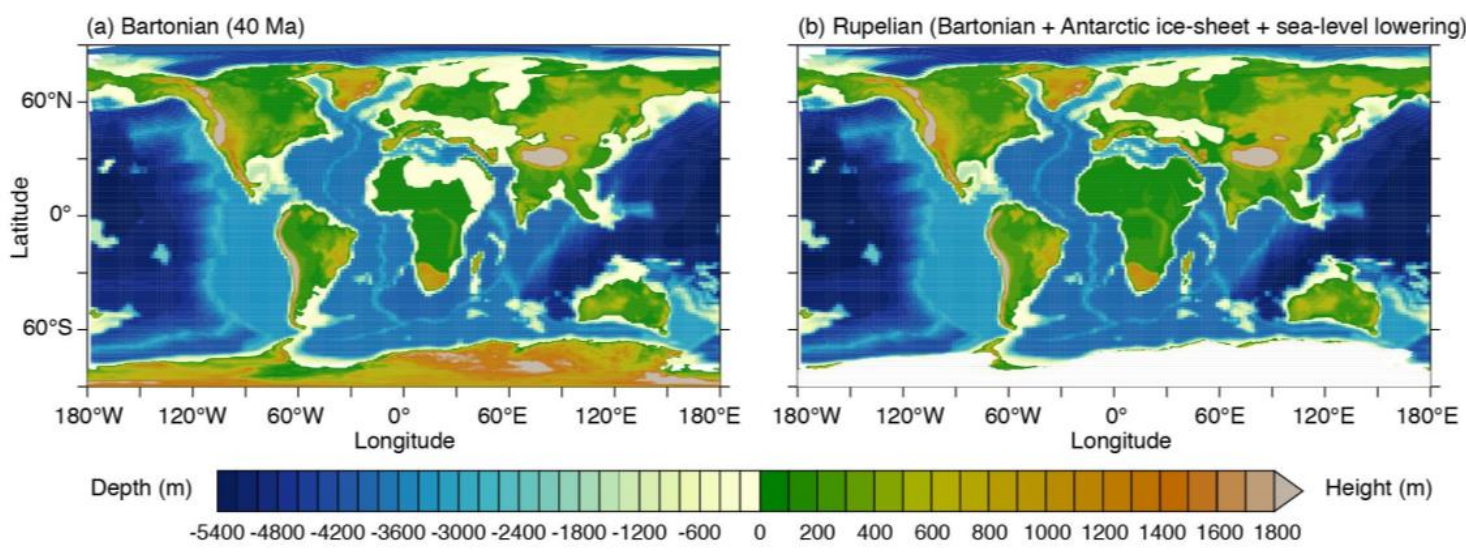

$-5400-4800-4200-3600-3000-2400-1800-1200-600 \quad 0 \quad 200 \quad 400 \quad 600 \quad 800 \quad 10001200140016001800$

Figure 1: Paleotopographic 40 Ma map: (a) standard version as used for simulations $4 \mathrm{X}$ to $2 \mathrm{X}$; (b) version adjusted with a homogeneous $70 \mathrm{~m}$ sea-level lowering (Poblete et al., 2021).

\subsection{Data compilation}

Simulation results were compared to MATR changes ( $\triangle \mathrm{MATR}$ ) documented by proxy-data records (Table $\mathrm{S} 1$ ). We compiled published MATR and CMMT proxy-data from various research fields: paleobotany (macrofossils and palynology), geochemistry (isotopic measurements on various material), and paleontology. The data were selected to range from the Lutetian (47.8 Ma) to the end of the Rupelian (27.8 Ma). This large time interval allows the representation of seasonal temperature changes parallel to the long-term cooling of the Eocene. The inclusion of data from the middle Eocene allows a comparison with simulations testing the effect of a $p \mathrm{CO}_{2}$ lowering alone, before AIS formation at the EOT. It is justified by the presence of paleobotanical records suggesting a strengthening of the seasons already from the Lutetian to the Priabonian (e.g. Li et al., 2014; Mosbrugger et al., 2005). Compiled MATR Eocene-Oligocene changes correspond either to the values given in original publications, when they were available and precise, or to values re-calculated from the original data. For 

(especially in terms of latitudes) and checked that the values obtained were consistent with the authors original interpretation of the paleoenvironmental context.

Some previously published seasonality increases were not here associated with changes in MATR, because they were either (1) estimated from other parameters, such as the length of the growing season, which do not allow the calculation of the

185 MATR (Hren et al., 2013), or (2) derived from qualitative data that cannot be specifically associated with temperature values (e.g., organism morphological changes such as teeth shape or plant tuber appearance; Joomun et al., 2010; Li et al., 2014). These sites are displayed on the maps, but are not analyzed quantitatively. In order to better estimate the impact of changes in temperature seasonality, the length of the plant growing season (i.e., the number of months with an average temperature above $10^{\circ} \mathrm{C}$ ) was recalculated using the formula of Grein et al., (2013) for data from the approximate coexistence analyses

190 (Table s1). Paleocoordinates for every locality were reconstructed using an online service of Gplate, the plate tectonic reconstruction models of Matthews et al. (2016) and a 40 Ma geography.

\subsection{Comparison of model and data $\triangle$ MATR}

Different analyses were made to evaluate the data-model agreement for temperature seasonality changes from the Priabonian to Rupelian (Table 2). First, a general agreement percentage was calculated from the direction of seasonality changes alone.

195 For this metric, model predictions are considered "good" for an individual site if they have the same sign as the data (i.e., positive model $\triangle \mathrm{MATR}$ at the location of a data point showing seasonality increase). For data indicating null $\triangle \mathrm{MATR}$, a good agreement was considered with model values ranging from -0.5 to $0.5^{\circ} \mathrm{C}$. This first metric enables us to assert the agreement between our simulation and qualitative data.

In addition, Priabonian to Rupelian seasonality changes were then compared to the model predictions, by (1) assessing their

200 correlation and (2) calculating the root of the mean squared distance between their values. These two analyses were performed using Rstudio software (version 4.0.3; R CoreTeam, 2020, Boston, USA). Given the limited number of quantitative Priabonian-Rupelian data $(n=15)$, the statistical correlation of data-model $\triangle$ MATR was assessed from average $\triangle$ MATR with the non-parametric Spearman rank test. Modelled MATR values were extracted from a $3^{\circ}$ longitude by $3^{\circ}$ latitude area surrounding each data locality. This test returns a coefficient, $\rho(r h o)$, which is a measure of the correlation

205 (ranging from -1 to 1 indicating total negative and positive linear correlations respectively and 0 the absence of correlation). The statistical significance of the correlation is described through the $p$-value. In this analysis, we used the common significance level, $\alpha$, of 0.05 (i.e., $p$-values $<0.05$ indicate significant correlations).

Data-model agreement for $\triangle$ MATR from Priabonian to Rupelian data was also assessed through the use of the Root Mean Squared Estimate (see Kennedy-Asser et al., 2020, and their figure S1 for a detailed presentation of the method). This 210 method consists in calculating the root of the mean squared distance between model and data values for comparable points. Conversely to the Spearman Rank Test for which mean $\triangle$ MATR estimations were used, the distance is here measured using the full range of estimates at each data locality (i.e., minimum and maximum $\triangle \mathrm{MATR}$ ). Note that because it considers the 
https://doi.org/10.5194/cp-2021-27

Preprint. Discussion started: 1 April 2021

(C) Author(s) 2021. CC BY 4.0 License.

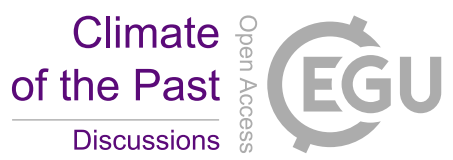

full range of $\triangle$ MATR, this method tends to underestimate the difference between model and data. The lower bound of modelled $\triangle$ MATR at each locality was calculated as the difference between the lower MATR value over the $3^{\circ} \mathrm{x} 3^{\circ}$ area centered around the locality for an Oligocene-like cold simulation (2X, 2X-ICE or 2X-ICE-SL) and the highest MATR value over the $3^{\circ} \times 3^{\circ}$ area for an Eocene simulation (4X or $\left.3 \mathrm{X}\right)$. For the upper bound, we used the difference between the higher MATR value over the same area for an Oligocene-like cold simulation and the lower MATR value for an Eocene simulation. The RMSE adjusted to $\triangle \mathrm{MATR}$ is written as follows:

$$
\operatorname{RMSE}_{\text {(MATR-changes) }}=\operatorname{SQRT}\left(\left(\cdot\left(\mathrm{MATR}_{\text {(diff-data) }}-\operatorname{MATR}_{\text {(diff-model) }}\right)^{2} / \mathrm{n}\right)\right.
$$

220 Where $M A T R_{\text {diff-data }}$ and $M A T R_{\text {diff-model }}$ are MATR Priabonian to Rupelian changes estimated by data and model respectively, and $n$ the total number of localities.

(a) $3 X-4 X$ (Annual)

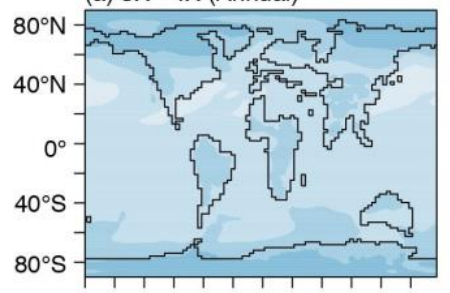

(e) $3 X-4 X($ JFM)
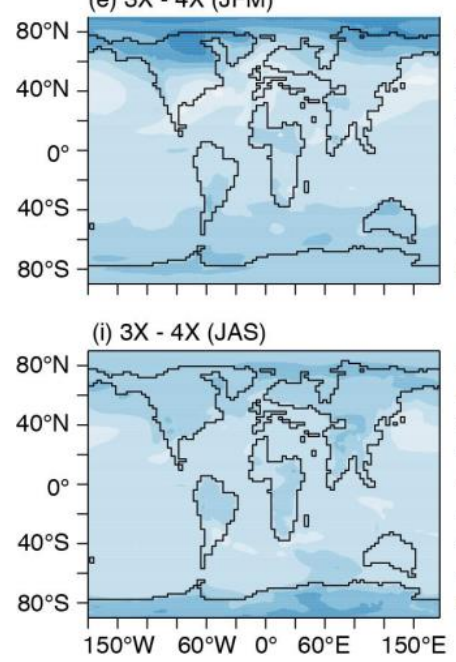

(b) $2 X-3 X$ (Annual)

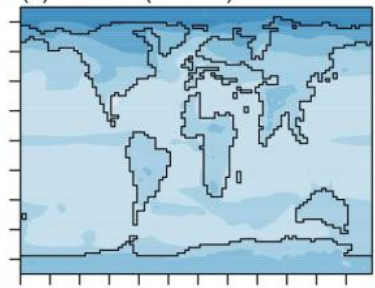

(f) $2 X-3 X(J F M)$

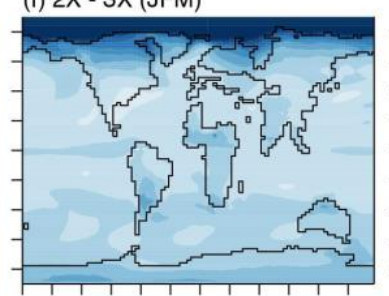

(j) $2 X-3 X(J A S)$

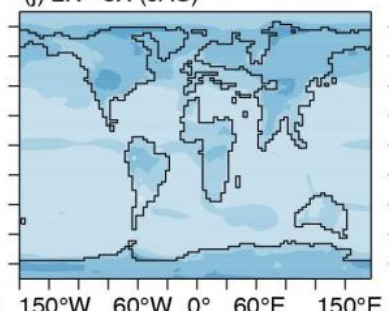

(c) 2X-ICE - 3X (Annual)

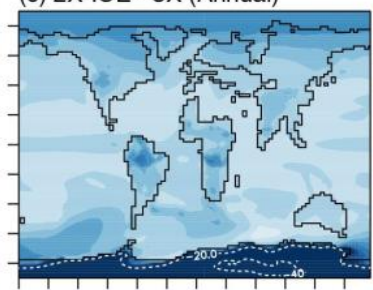

(g) 2X-ICE - 3X (JFM)

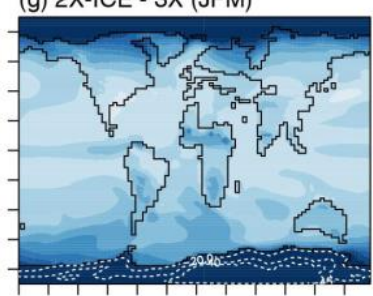

(k) 2X-ICE - 3X (JAS)

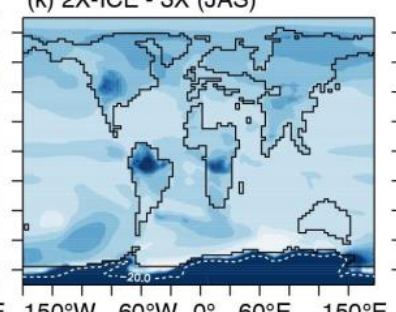

(d) 2X-ICE-SL - 3X (Annual)

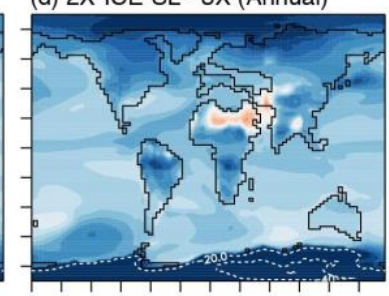

(h) 2X-ICE-SL - 3X (JFM)

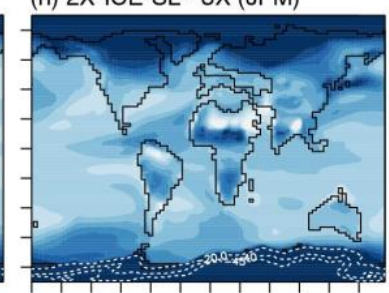

(I) $2 X-I C E-S L$ - $3 X$ (JAS)

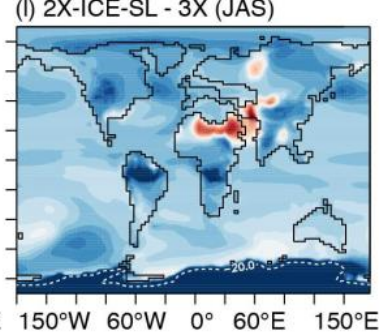

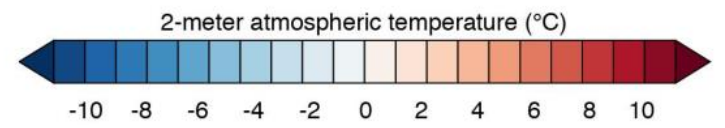

Figure 2: 2-meter air temperature changes $\left({ }^{\circ} \mathrm{C}\right)$. JFM: averaged over January to March, JAS: averaged over July to

September. 

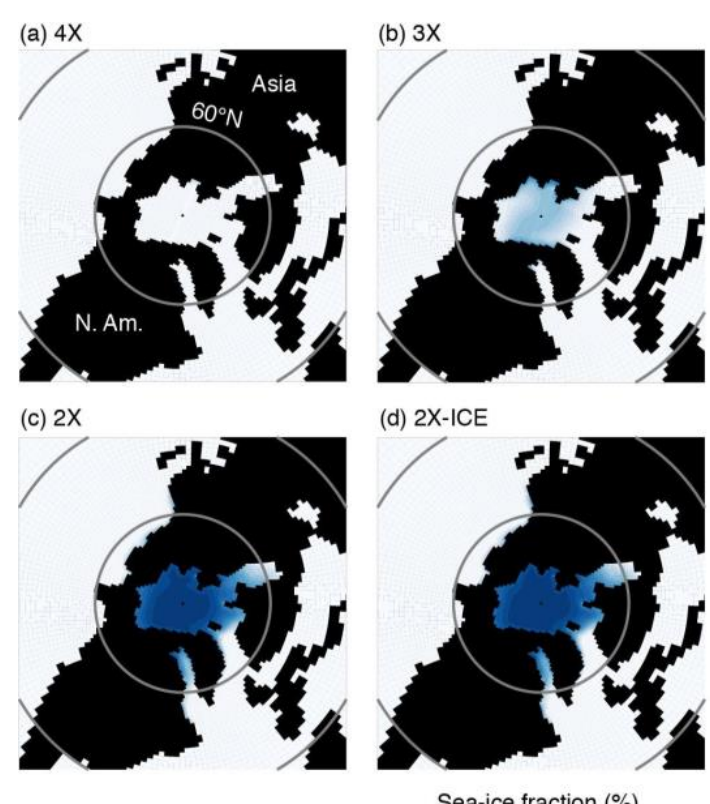

(d) $2 X-I C E$

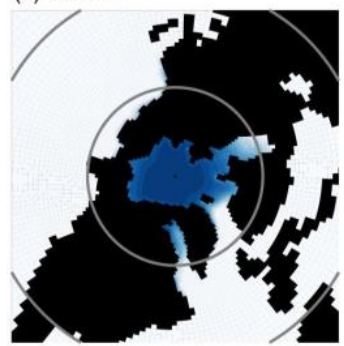

(e) 2X-ICE-SL
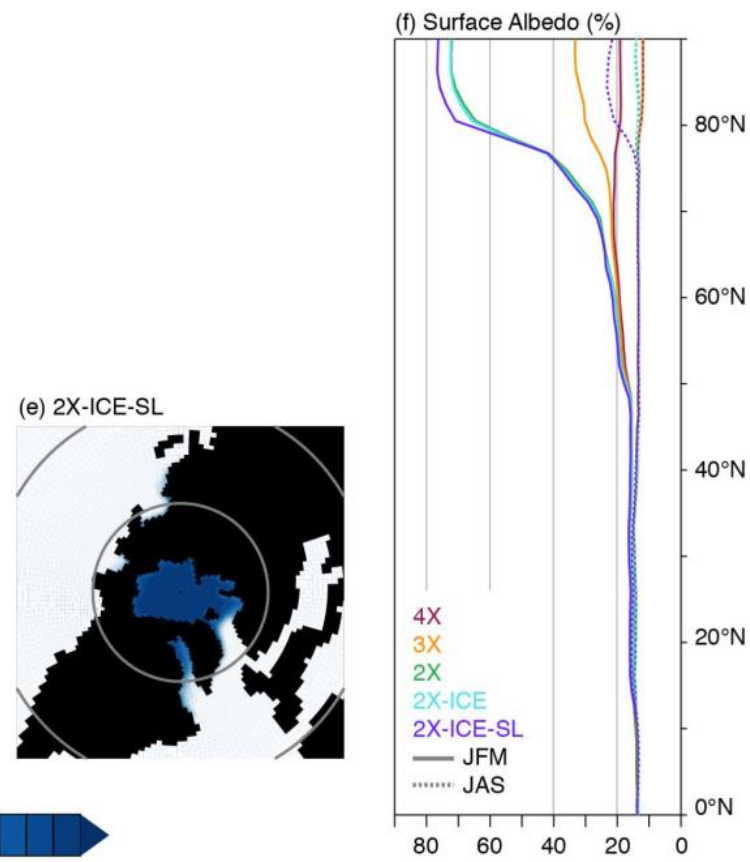

Figure 3: Northern Hemisphere winter sea-ice fraction and surface albedo $(\%)$

\section{Results}

\subsection{Modelled response to $p \mathrm{CO}_{2}$ lowering}

\subsubsection{Temperature changes}

Atmospheric temperatures decrease strongly in our different experiments (Table 1). The halving of $p \mathrm{CO}_{2}$ alone (i.e. without AIS formation and sea level drop) induces a global cooling of $5.8^{\circ} \mathrm{C}$ and $5.0^{\circ} \mathrm{C}$ for the air temperature and the surface ocean respectively. Temperature changes are characterized by polar amplification, with a stronger winter cooling at high-latitudes (Figure 2. a,b,e,f,i,j). This phenomenon is well explained by the combined effect of albedo and sea-ice feedback. The $p \mathrm{CO}_{2}$ drop enables sea-ice growth over the Arctic and, to a lesser extent, the subsistence of snow on the ground during the cold season, which increases winter surface albedo (Figure 3). In addition, seasonal sea-ice expansion limits ocean-to-air heat transfer at highest Northern latitudes and contributes to further winter cooling.

\subsubsection{MATR increase zones}

Along with its effect on temperatures, $p \mathrm{CO}_{2}$ decrease induces zonal $\triangle \mathrm{MATR}$ including (1) an increase of MATR at highlatitudes, (2) a decrease of MATR across most mid-latitudes, and (3) moderate changes at low-latitudes (Figure 4. a,b; see also Figure S2 for absolute MATR values). The large MATR increase at high northern latitudes is triggered by the 
https://doi.org/10.5194/cp-2021-27

Preprint. Discussion started: 1 April 2021

(C) Author(s) 2021. CC BY 4.0 License.

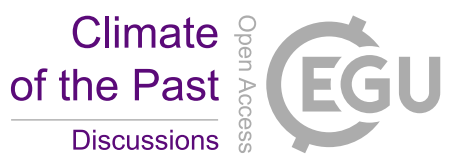

preferential lowering of winter temperatures aforementioned. Furthermore, the areas of colder winters and broader MATR become larger as $p \mathrm{CO}_{2}$ decreases: MATR increases from $60^{\circ} \mathrm{N}$ poleward between $4 \mathrm{X}$ and $3 \mathrm{X}$, to $50^{\circ} \mathrm{N}$ poleward between $4 \mathrm{X}$ and $2 \mathrm{X}$ (Figures 4 and S3). In contrast, Antarctica shows moderate changes $\left(3^{\circ} \mathrm{C}\right.$ from $3 \mathrm{X}$ to $\left.2 \mathrm{X}\right)$ compared to high Northern latitudes $\left(6^{\circ} \mathrm{C}\right.$ MATR increase from $3 \mathrm{X}$ to $\left.2 \mathrm{X}\right)$. This is because ice-free Antarctica is characterized by high variability of albedo as the continent oscillates from snow-free to snow-covered soil within a year, resulting in highly variable intra-annual temperatures (Figure 4).

(a) $3 X-4 X$

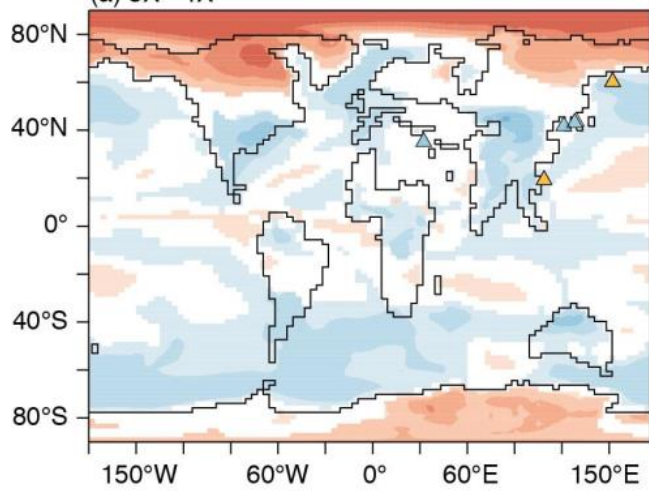

(c) $2 X-I C E-3 X$

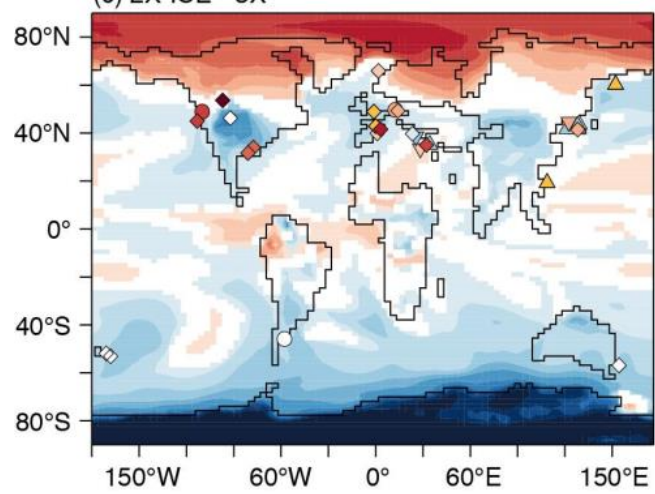

(b) $2 X-3 X$

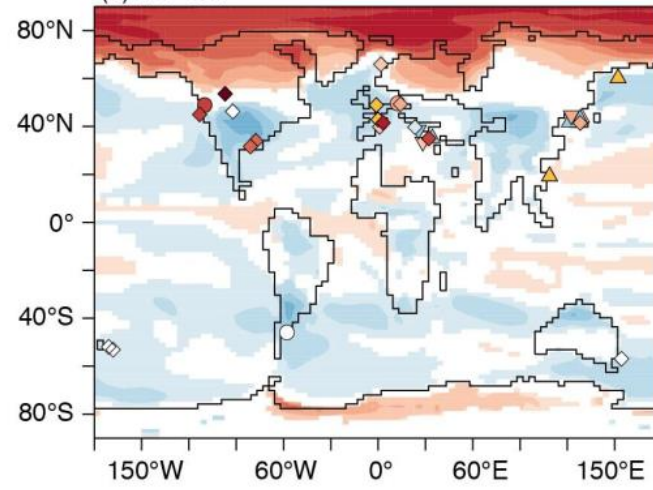

(d) $2 X-I C E-S L-3 X$

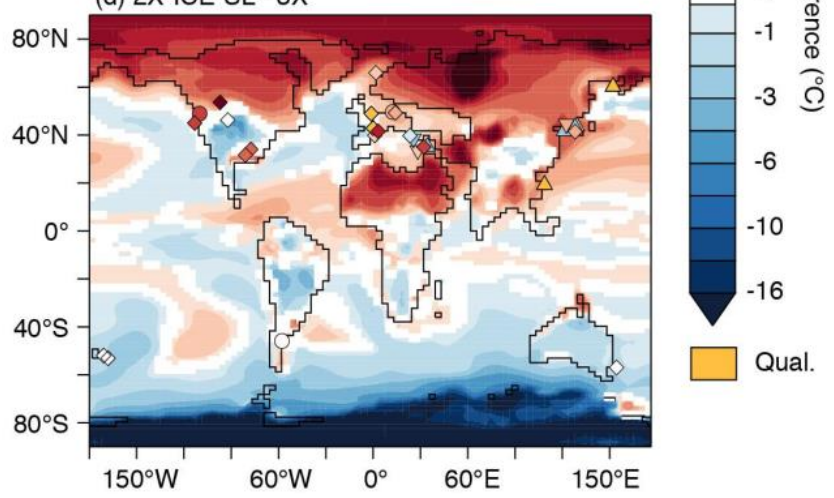

250

Figure 4: Mean Annual Temperature Range changes $\left({ }^{\circ} \mathrm{C}\right)$. Shadings are model differences calculated with a Student $\mathrm{t}$-test over the last 100 years of comparative simulations (95\% confidence); white areas indicate no significant change in MATR. Symbols correspond to $\triangle$ MATR from proxy-data for different time steps: Priabonian-Lutetian (triangles); Rupelian-Lutetian (deltas); Rupelian-Bartonian (circles); Rupelian-Priabonian (diamonds). Orange symbols indicate qualitative values describing a temperature seasonality increase. In case of proxies reconstructing a range of equally probable values (e.g., Coexistence approach), values shown are mean values. References for every data site are displayed on Figure 7 and available in the data compilation provided in Table S1. 
https://doi.org/10.5194/cp-2021-27

Preprint. Discussion started: 1 April 2021

(C) Author(s) 2021. CC BY 4.0 License.

(c) (i)

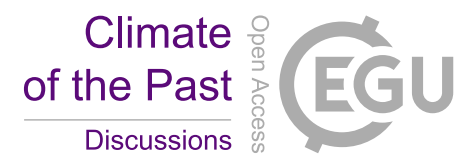

\subsubsection{MATR decrease zones}

Areas with decreased seasonality are characterized by summer cooling that exceeds winter cooling, which reduces the MATR (Figure 2 and 4). The widest zones with decreasing MATR are located within the $30-50^{\circ} \mathrm{N}$ latitudinal band, across North America, Western Europe, Central Asia, and 30-50 ${ }^{\circ} \mathrm{S}$ for South America and Australia (Figure 4). To a lesser extent, seasonality decreases in Amazonia, equatorial Africa and India (Figure 4). This phenomenon is well explained by two distinct chains of reaction. First, the $p \mathrm{CO}_{2}$ drop flattens the P-E (precipitation minus evaporation, or net precipitation) latitudinal gradient caused by a general increase of P-E values between $50^{\circ} \mathrm{S}$ and $50^{\circ} \mathrm{N}$, notably in North America and East Asia (especially in part of India, Mongolia and SE Asia), and an overall P-E decrease at high latitudes in both hemispheres (Figure 5 a-d). Summer evaporation is increased in zones with increased moisture (i.e. where P-E increases, not shown). This results in larger latent heat fluxes during summer (Figure $5 \mathrm{e}, \mathrm{f}$ ) and thus in a greater decrease in summer temperatures (Figure $2 \mathrm{j}$ ). Summer cooling is strengthened through vegetation feedback: P-E increase favors net primary productivity which in turn contributes to evaporation and summer warmth loss (Figure $5 \mathrm{~g}, \mathrm{~h}$ ). Secondly, changes in ocean temperature have a strong impact on continental MATR in several areas at mid latitudes, such as in Patagonia and Europe. In these areas, cold air masses originating from the nearest oceans (North Atlantic and South Pacific) are brought by westerly winds during summer. They favor a lowering of temperatures during this season and thus, a lowering of the MATR (Figure 6). These cold air masses result from the regional increase in low-level cloud cover during summer (5 to $15 \%$ higher cloud fraction between

$27540-60^{\circ}$; Figure 6 d,h, S4) which increases planetary albedo. In addition, the presence of sea-ice at the North Pole (Figure 3 $\mathrm{b}, \mathrm{c})$ limits heat loss via the atmosphere during winter and results in a greater SST cooling during summer which significantly impacts European MATR (Figure S5).

\subsection{Modelled response to Antarctic Ice Sheet and sea-level drop}

\subsubsection{Antarctic Ice Sheet alone}

280 AIS formation is responsible for a supplementary $0.9^{\circ} \mathrm{C}$ and $0.3^{\circ} \mathrm{C}$ cooling of the air temperature and the surface ocean respectively (Table 1). It induces striking mean annual temperature differences, reaching $-35^{\circ} \mathrm{C}$ above the continent (Figures 2 and S6). Its effect on atmospheric temperature varies regionally and is more significant over the Southern Ocean and Australia. In contrast with Arctic sea-ice which increases seasonality at highest northern latitudes, the AIS decreases southern latitude temperature seasonality (Figures 4 and S6). Indeed, simulations with the AIS have year-long white soil and high stable surface albedo, which reduces seasonal temperature variability (Figure 3.g-l). 
(a) Net precipitation $3 \mathrm{X}$ (P-E)

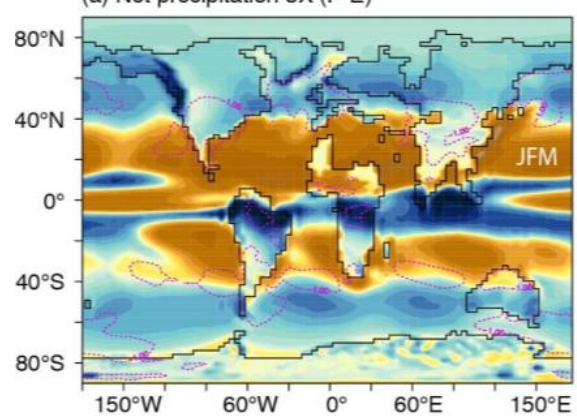

(c) Net precipitation changes, $2 \mathrm{X}-3 \mathrm{X}$

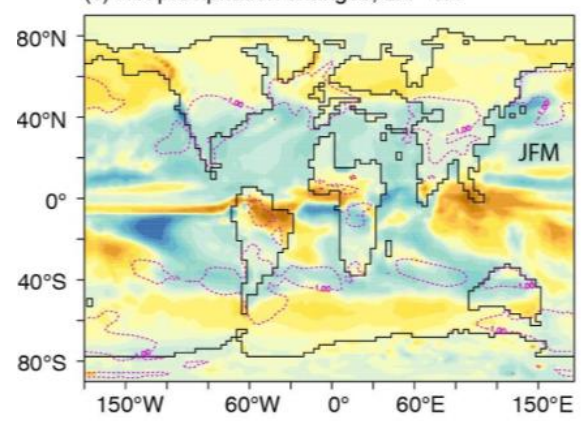

(e) Latent heat fluxes changes, $2 X-3 X$

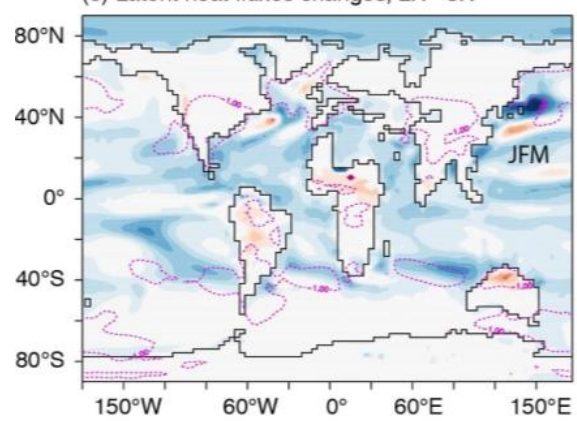

(g) Net Primary Prod. changes, 2X - 3X

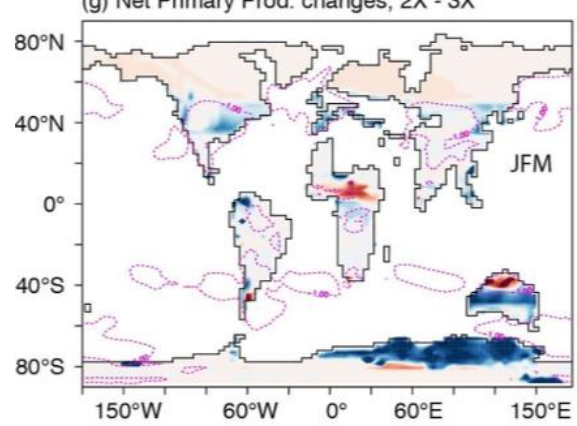

(b) Net precipitation $3 \mathrm{X}(\mathrm{P}-\mathrm{E})$

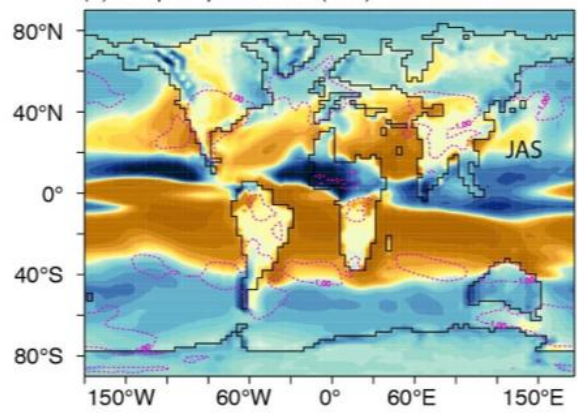

(d) Net precipitation changes, $2 X-3 X$
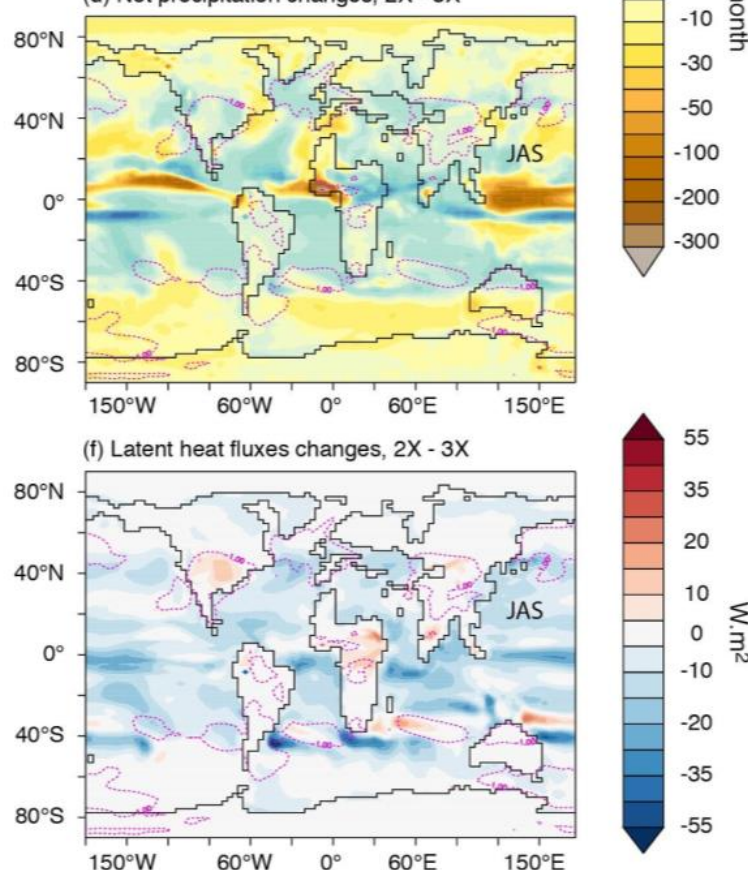

(h) Net Primary Prod. changes, $2 X-3 X$

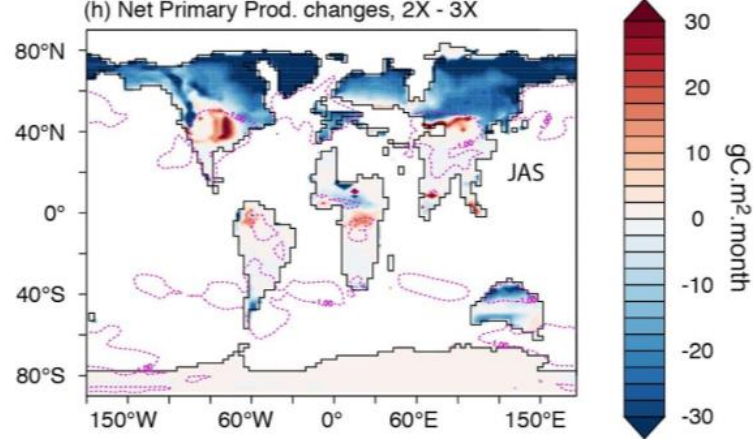

Figure 5: (a,b) Net precipitation (precipitation - evaporation, P-E) in JAS and JFM for the late Eocene simulation 3X. (c,d) Changes associated with $\mathrm{pCO} 2$ drop from $3 \mathrm{X}$ to $2 \mathrm{X}$ (difference shown are $2 \mathrm{X}$ minus $3 \mathrm{X}$ ) for net precipitation (c,d), latent heat fluxes (e,f) and net primary production $(\mathrm{g}, \mathrm{h})$. Dashed Magenta lines contour MATR decreasing zones in $2 \mathrm{X}$ minus $3 \mathrm{X}$ simulations (blue zones in Figure 4.b). 
(a) Western Europe: 3X - JFM

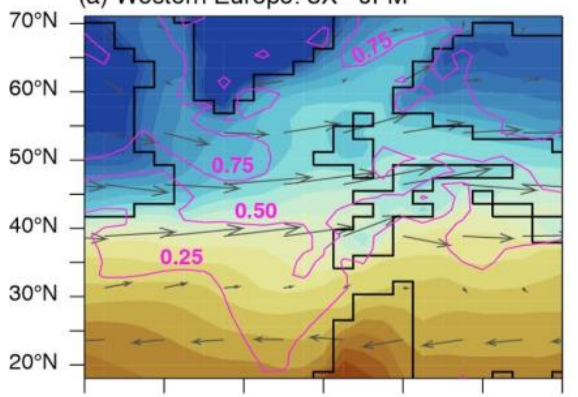

(c) Western Europe: 2X - 3X (JFM)

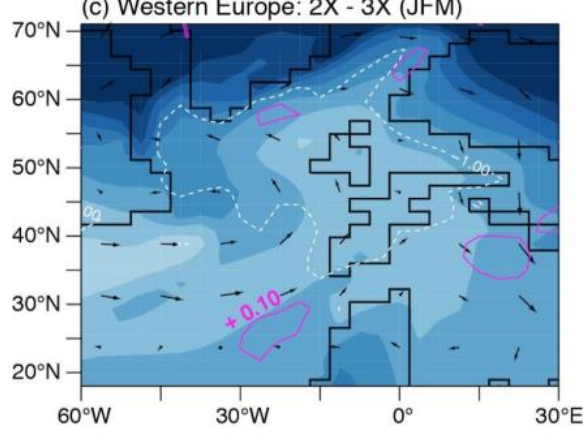

(e) Patagonia: 3X - JFM
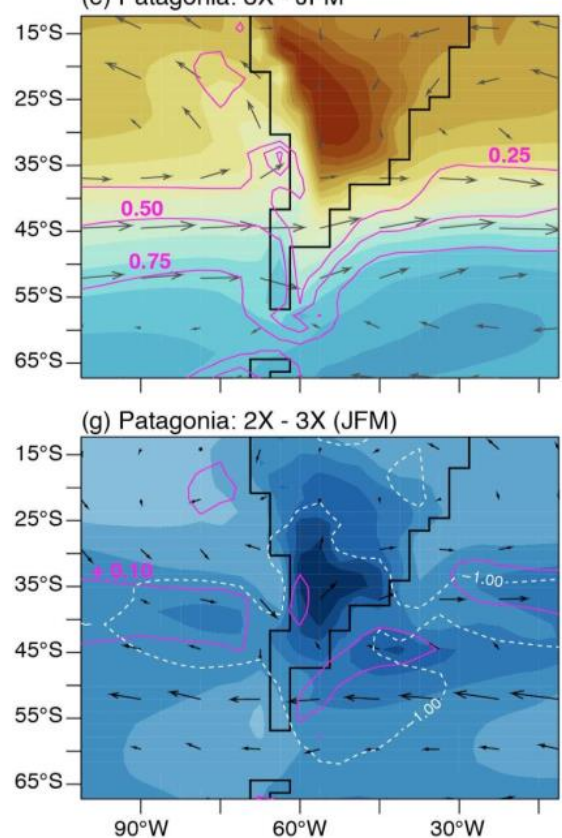

(b) Western Europe: $3 X$ - JAS

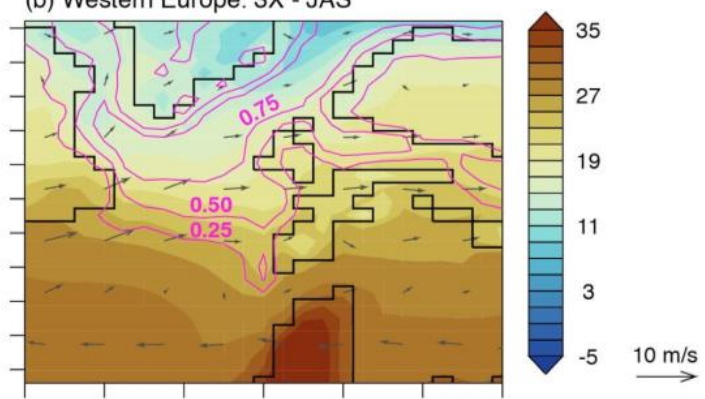

(d) Western Europe: 2X - 3X (JAS)

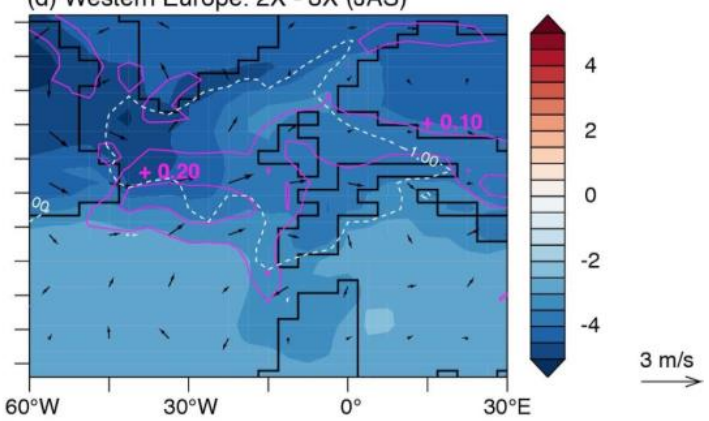

(f) Patagonia: $3 \mathrm{X}$ - JAS

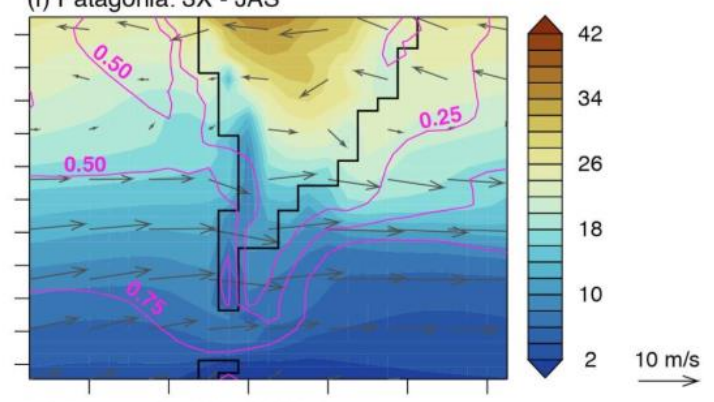

(h) Patagonia: $2 \mathrm{X}-3 \mathrm{X}$ (JAS)

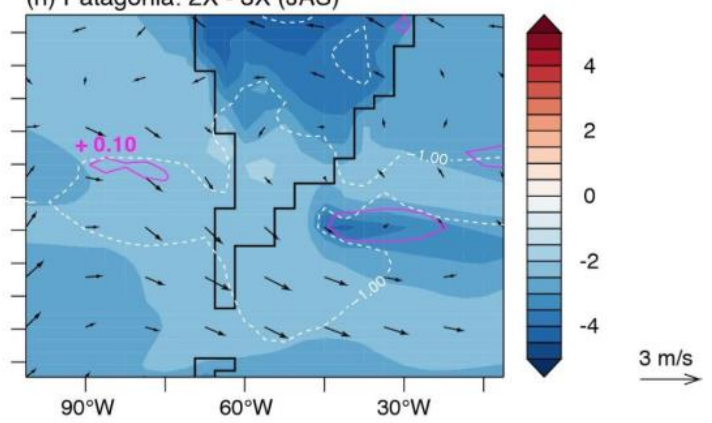

Figure 6: 2-meter atmospheric temperature (shadings expressed in ${ }^{\circ} \mathrm{C}$ ), low-level cloudiness (Magenta line contours expressed in \%) and $850 \mathrm{hPa}$ winds (m. $\mathrm{s}^{-1}$, arrows) across western Europe and Patagonia. White dashed lines contour MATR decreasing zones in 2X minus 3X simulations (blue zones in Figure 4.b). Magenta lines contour low-level cloud fraction (a,b,e,f) and low-cloud fraction changes (c,d,g,h). 


\subsubsection{Sea-level drop}

In addition, sea-level decrease is responsible for a $1.0^{\circ} \mathrm{C}$ mean annual global $2 \mathrm{~m}$-air cooling $\left(0.7^{\circ} \mathrm{C}\right.$ for surface oceans) and results in considerable regional temperature changes in areas with important land-sea distribution changes (Table 1 and Figure S6). The increased proportion of land over ocean enhances latent and sensible heat fluxes during boreal winter, which reduces CMMT and conversely reduces energy fluxes during boreal summer, which increases summer warmth (Figures 2, S3 and S6). The numerous areas of winter cooling and summer warming resulting from land fraction increase provoke a wide spatial extension of the MATR reinforcement zone (Figure $4 \mathrm{~d}$ ). The zonal distribution of seasonal temperature changes generated by $p \mathrm{CO}_{2}$ drop and AIS formation is dismantled. East Africa, Western Asia and Russia are the most impacted areas, following proto-paratethys retreat and the emergence of the Arabic Peninsula (Figure 1). More moderate seasonality changes are also visible as a result of sea retreats of smaller extent, such as the emergence of the Florida platform and the modification of the East Asian coastlines (Figure $4 \mathrm{~d}$ ).

\subsection{Model-data comparison}

\begin{tabular}{|c|c|c|c|c|c|c|}
\hline & $\mathbf{2 X}-\mathbf{4 X}$ & $\mathbf{2 X}-\mathbf{I C E}-\mathbf{4 X}$ & $\mathbf{2 X}-\mathbf{I C E}-\mathbf{S L}-\mathbf{4 X}$ & $\mathbf{2 X}-\mathbf{3 X}$ & $\mathbf{2 X}-\mathbf{C C E}-\mathbf{3 X}$ & $\mathbf{2 X}$-ICE-SL -3X \\
\hline $\begin{array}{c}\text { Mean MATR } \\
(\text { model } \text { - data })\end{array}$ & $5.3^{\circ} \mathrm{C}$ & $5.8^{\circ} \mathrm{C}$ & $3.9^{\circ} \mathrm{C}$ & $4.6^{\circ} \mathrm{C}$ & $5.1^{\circ} \mathrm{C}$ & $3.2^{\circ} \mathrm{C}$ \\
\hline RMSE & $5.0^{\circ} \mathrm{C}$ & $5.3^{\circ} \mathrm{C}$ & $4.1^{\circ} \mathrm{C}$ & $4.8^{\circ} \mathrm{C}$ & $5.0^{\circ} \mathrm{C}$ & $3.8^{\circ} \mathrm{C}$ \\
\hline$\%$ & $5,8 \%$ & $5,8 \%$ & $35,3 \%$ & $0,0 \%$ & $0,0 \%$ & $58,8 \%$ \\
\hline rho & $\begin{array}{c}0.21 \\
(p=0.45)\end{array}$ & $\begin{array}{c}0.35 \\
(p=0.20)\end{array}$ & $\begin{array}{c}0.57^{* *} \\
(p=0.02)\end{array}$ & $\begin{array}{c}0.20 \\
(p=0.47)\end{array}$ & $\begin{array}{c}0.37 \\
(p=0.17)\end{array}$ & $\begin{array}{c}0.56^{* *} \\
(p=0.03)\end{array}$ \\
\hline
\end{tabular}

Table 2: RMSE for $\triangle$ MATR between the Priabonian and the Rupelian. The line "\%" give the percentage of sites where the direction of $\triangle$ MATR is adequately modelled (e.g., the model described a MATR reinforcement in the zone where data indicate MATR increase). Modelled MATR estimates were considered as positive when $>0.5$, negative when $<0.5$, or null when ranging $[-0.5 ; 0.5]$. "rho" indicates the strength of the correlation estimated with the Spearman Rank test, with associated p-values ("p"). Significant correlations are indicated in bold and with **.

\subsection{1 $p \mathrm{CO}_{2}$ lowering}

315 The $\triangle \mathrm{MATR}$ described by the $p \mathrm{CO}_{2}$ drop experiments (from $3 \mathrm{X}$ or $4 \mathrm{X}$ to $2 \mathrm{X}$ ) show neither a good agreement with middle to late Eocene, nor with late Eocene to early Oligocene data estimates (Figure $4 \mathrm{a}, \mathrm{b}$ and $6 \mathrm{~b}$ ). The simulations predict no change or a MATR decrease in areas where the Lutetian-Priabonian data points $(n=6$, triangles, Figure 4) describe increased seasonality (Figure $4 \mathrm{a}, \mathrm{b})$. Priabonian-Rupelian $\triangle \mathrm{MATR}$ modelled through $4 \mathrm{X}$ to $2 \mathrm{X}$ and $3 \mathrm{X}$ to $2 \mathrm{X} p \mathrm{CO}_{2}$ drop $\left(-1.8^{\circ} \mathrm{C}\right.$ and $\left.1.0^{\circ} \mathrm{C}\right)$ are lower than data estimates at similar localities $\left(3.6^{\circ} \mathrm{C}\right.$, Figure $\left.7 \mathrm{~b}\right)$. The use of the simulation $4 \mathrm{X}$ instead of $3 \mathrm{X}$ for the late Eocene stage slightly increases the percentage of agreement for the sign of the $\triangle \mathrm{MATR}$, but this result only depends 
https://doi.org/10.5194/cp-2021-27

Preprint. Discussion started: 1 April 2021

(c) Author(s) 2021. CC BY 4.0 License.

(c) (i)

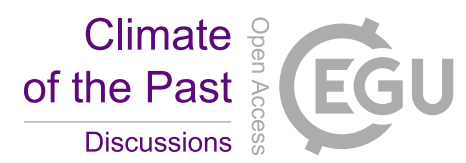

on one high-latitude data-point for which a positive $\triangle \mathrm{MATR}$ is predicted with a larger $p \mathrm{CO}_{2}$ drop (Table 2, line '\%', datapoint 12 in Figure 7.a). In addition, $p \mathrm{CO}_{2}$ drop alone leads to zonal $\triangle \mathrm{MATR}$ which do not transcribe the spatial heterogeneity visible in data. This misfit is visible through high RMSE scores and the absence of significant correlation between modelled $\triangle \mathrm{MATR}$ resulting from $p \mathrm{CO}_{2}$ drop (simulations $2 \mathrm{X}-4 \mathrm{X}$ and $2 \mathrm{X}-3 \mathrm{X}$ ) and $\triangle \mathrm{MATR}$ described by proxydata (Table 2). Two data-model agreement patterns are nevertheless to be noted: (1) Regardless of their values (which are higher in data than in our simulations), the northernmost data points are inside or surround the high-latitude seasonality strengthening zone we modelled (Figure 4, data-points 9,5,12 on Figure 7); (2) none of the Southern Hemisphere data localities showing no seasonality change are located within zones MATR increase zones (Figure $4 \mathrm{a}, \mathrm{b}$ ).

(a)

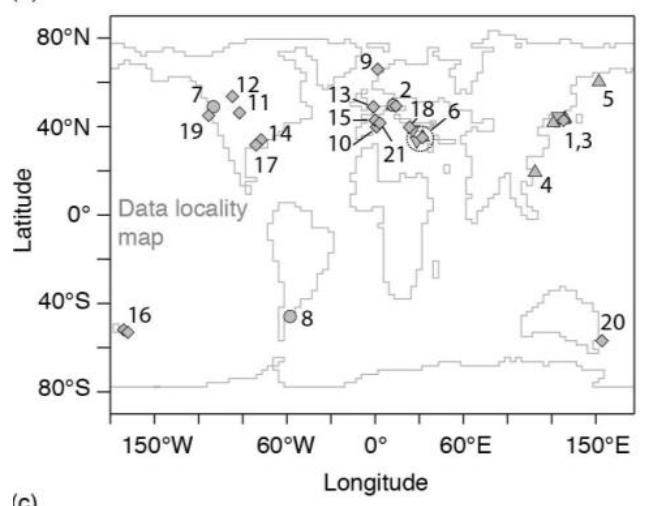

(c)

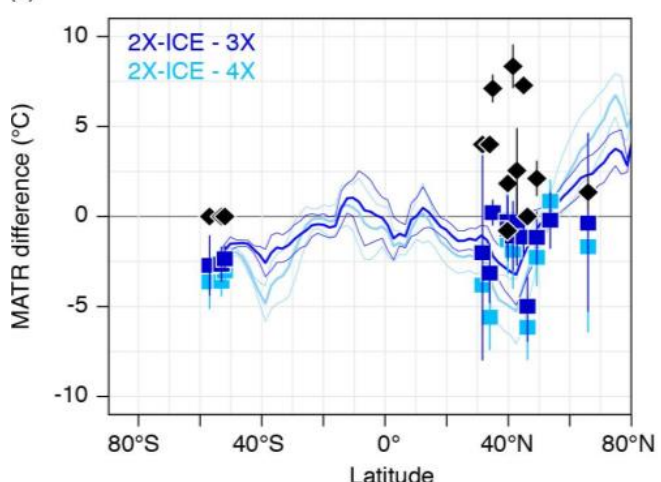

(b)

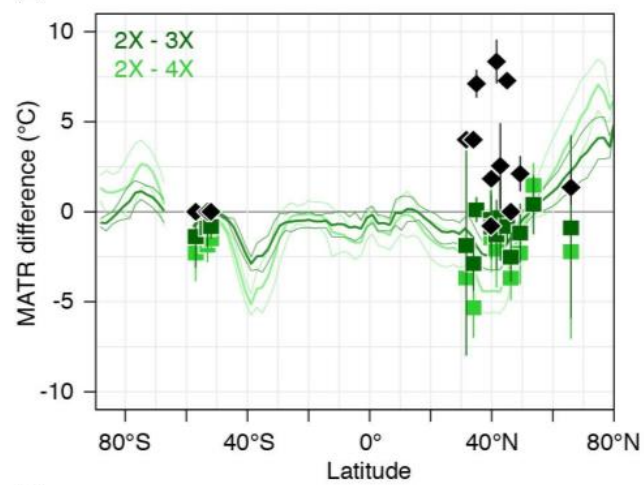

(d)

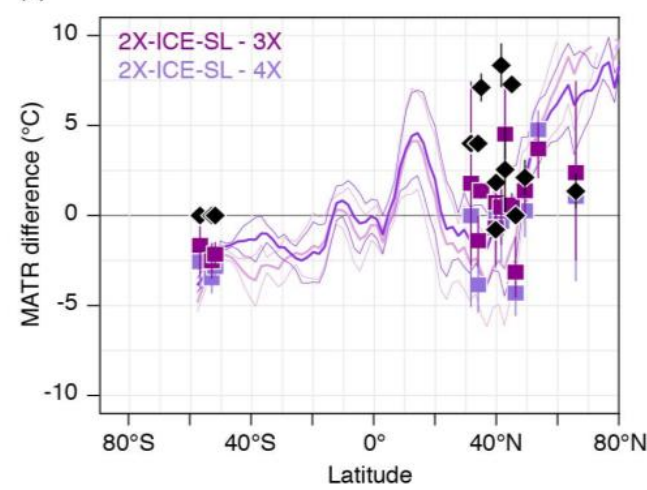

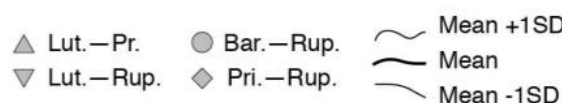

Figure 7 - data-model comparison of $\triangle$ MATR from the Priabonian to the Rupelian. (a). Map of all data $\triangle$ MATR estimates compiled in this study (symbols refer to the time period compared for the calculation of the MATR shift, see also Table S1). (b-d). Comparison of data estimates of Priabonian-Rupelian $\triangle$ MATR (black diamonds) to modelled $\triangle$ MATR at same localities (colored squares, calculated on $3 \times 3^{\circ}$ area) from different pairs of simulations. Error bars are minimum and maximum data estimates of $\triangle$ MATR. Bold colored lines indicate the continental latitudinal gradient of $\triangle$ MATR (all longitudes averaged per degree of latitude); thinner lines are the standard deviation around the average. 


\subsubsection{Antarctic ice-sheet and sea-level}

The formation of the AIS alone does not result in a better agreement between the modelled and Priabonian-Rupelian $\triangle$ MATR estimates. It is even slightly reduced (Table 2). The reinforcement of the MATR lowering zone at high-southern latitudes increases the data-model misfit with the few data-points in New-Zealand, Patagonia and Australia which indicate null $\triangle$ MATR (points 16,8 and 20 on Figure 7.a; Figure 4.c and Figure 7.c). There is still no significant correlation between $\triangle$ MATR from the model and differences observed documented by proxy-data (Spearman rank test: rho $=0.35$ and $\mathrm{p}$-value $=$ 0.20 (2X-ICE - 4X) and rho: 0.37, p-value = 0.17 (2X-ICE - 3X), Table 2).

Geographic changes associated with sea-level drop result in a better agreement with data $\triangle$ MATR (Figure 4.d and Figure

345 7.d). The largest continental fraction changes affect the MATR on a broad geographic scale and allow for a better agreement, even with several distant data points. For example, the retreat of the proto-paratethys reinforces the area of MATR increase at the high northern latitudes which spreads toward North America and creates a better fit with data estimates located on the Pacific Coast. Similarly, coastline changes along the eastern part of Africa and Western Asia cause an increase in seasonality in Anatolia and Central/Western Europe, improving the fit between model and data. These changes in temperature seasonality result in a reduction of 2 to 2.5 months in the duration of the plant growing season (as reconstructed with the formula of Grein et al., 2013; Table S1). Smaller changes in coastlines such as in Florida, Kamchatka Peninsula or along the East Asian coast increase seasonality at a regional scale and improve the data-model fit (data-points 1, 3-5, 14, 17). The simulation still underestimates $\triangle$ MATR across the EOT (Figure 7.d; Table 2). Modelled MATR using simulation 2X-ICESL for the Rupelian stage are the only ones showing significant correlation with proxy-data $\triangle$ MATR (Table 2). Changes are equally correlated to proxy-data Priabonian-Rupelian $\triangle \mathrm{MATR}$, independently of the late Eocene simulation (4X or $3 \mathrm{X}$ ) used as initial stage (Spearman rank test: rho $=0.56$ and 0.57 , p-value $<0.05$, Table 2). This better agreement is also visible in RMSE analysis, with the lowest data-model distance observed for the couple 2X-ICE-SL - 3X (Table 2). A smaller datamodel difference is also described for $2 \mathrm{X}$-ICE-SL - 3X (as compared to 2X-ICE-SL - 4X) by other indicators, notably (1) a $3.2^{\circ} \mathrm{C}$ mean difference, as compared to a $3.9^{\circ} \mathrm{C}$ offset for $2 \mathrm{X}$-ICE-SL - 4X (2X-ICE-SL - 3X) and (2) the percentage of values for which a $\triangle$ MATR in the good direction is predicted (23.5\% higher with $3 \mathrm{X}$; Table 2$)$.

\section{Discussion}

\subsection{Implication for mechanisms of late Eocene to early Oligocene seasonality changes}

\subsubsection{Model climate sensitivity and climate response to EOT forcing}

$\triangle \mathrm{MATR}$ across the EOT are better predicted with the lower $p \mathrm{CO}_{2}$ simulation $3 \mathrm{X}$ for the late Eocene stage. In addition, with

365 a mean global cooling of $2.7^{\circ} \mathrm{C}$ between $3 \mathrm{X}$ and $2 \mathrm{X}$ simulations, surface temperature changes are also in agreement with the mean changes described in marine proxies across the EOT (i.e., difference of $2.9^{\circ} \mathrm{C}$ between $38-34.2$ and $33.7-30 \mathrm{Ma}$, Hutchinson et al., 2021). The best fit with a limited drop of $p \mathrm{CO}_{2}$ reflects the high climate sensitivity of our model (i.e., the 
average temperature change per doubling of the $\mathrm{PCO}_{2}$ at model equilibrium; PALEOSENS, 2012). This high sensitivity is also highlighted in our experiments of $p \mathrm{CO}_{2}$ halving from 1120 to $560 \mathrm{ppm}(2 \mathrm{X}-4 \mathrm{X})$, which result in a dramatic mean annual global cooling $\left(5.8^{\circ} \mathrm{C}\right.$ for MAT, $5^{\circ} \mathrm{C}$ for SST). Such temperature difference is high compared to previous modelling studies which describe a 3 to $4^{\circ} \mathrm{C}$ surface atmospheric temperature difference under similar forcing, and the $2.9^{\circ} \mathrm{C}$ cooling found in marine proxies across the EOT (Hutchinson et al., 2021). The $\mathrm{pCO}_{2}$ of $4 \mathrm{X}$ and $2 \mathrm{X}$, are more generally used in simulations to represent the transition to an icehouse world (e.g., Baatsen et al., 2020; Goldner et al., 2014; Kennedy-Asser et al., 2019). Although $4 \mathrm{X}$ is likely too high $p \mathrm{CO}_{2}$ for the late Eocene (values rather approximate $\sim 800 \mathrm{ppm}$ from the Lutetian to the Priabonian; Foster et al., 2017), the use of this value is justified to better reconstruct high-latitudes temperatures (Huber and Caballero, 2011). A good agreement between warm conditions and Bartonian SST data has also been recently shown by other experiments using the model IPSL-CM5A2 with middle / late Eocene boundary conditions (Tardif et al., 2020; Toumoulin et al., 2020). We thus argue that the use of the $4 \mathrm{X}$ simulation is appropriate to study possible variations of $p \mathrm{CO}_{2}$ during the Eocene, but the use of the $3 \mathrm{X}$ simulation is better to study the changes between the Priabonian and the Rupelian.

\subsubsection{Temperature seasonality changes through the late Eocene}

The evolution of the different climate parameters responsible for $\triangle \mathrm{MATR}$ is consistent with several aspects of former studies. First, earlier modelling experiments have described albedo and sea-ice increase resulting in polar amplification of the cooling (e.g. Baatsen et al., 2020; Kennedy-Asser et al., 2019) and a reinforcement of temperature seasonality (Eldrett et al., 2009). The strengthening and expansion of the high Northern latitudes MATR increase zone with $p \mathrm{CO}_{2}$ lowering is a good explanation for the dramatic seasonality increase at high latitudes suggested by some studies (Eldrett et al., 2009; Wolfe, 1992; Zanazzi et al., 2015). In addition, changes in the importance and distribution of net precipitation (i.e., precipitation - evaporation) resulting from $p \mathrm{CO}_{2}$ lowering agree with former theoretical and modelling work suggesting an intensified hydrological cycle under higher $p \mathrm{CO}_{2}$ (e.g., Carmichael et al., 2016; Hutchinson et al., 2018). This phenomenon results from a greater capacity of the air to retain moisture and more intense atmospheric convection phenomena (Allen and Ingram, 2003; Carmichael et al., 2016; Held and Soden, 2006). Finally, the increase of low cloud cover is consistent with former model studies describing higher fraction of low-level clouds under lower $p \mathrm{CO}_{2}$ (Baatsen et al., 2020; Caballero and Huber, 2013; Zhu et al., 2019). Such a trend could be explained by a higher efficiency of cloud water conversion into precipitation in warmer climates (Zhu et al., 2019). Nevertheless, although a low-level cloud cover increase due to $p \mathrm{CO}_{2}$ drop is consistent with increased air moisture in Western Europe at the EOT (Kocsis et al., 2014), this parameter remains poorly constrained in paleoclimate archives and modelling analysis (Lunt et al., 2020; Sagoo et al., 2013).

Despite these agreements, the MATR evolution resulting from $p \mathrm{CO}_{2}$ drop does not clearly match data estimates whether they correspond to both Lutetian-Priabonian or to Priabonian-Rupelian changes. This suggests that the temperature seasonality compiled can only be partly explained by a $p \mathrm{CO}_{2}$ drop. Since zonal $\triangle \mathrm{MATR}$ patterns are visible with a $p \mathrm{CO}_{2}$ drop of $1 \mathrm{PAL}$ (either from $4 \mathrm{X}$ to $3 \mathrm{X}$ or from $3 \mathrm{X}$ to $2 \mathrm{X}$ ) we hypothesize that they likely occurred before the AIS onset, and that high northern latitudes were among the first to observe seasonality strengthening. However, the major part of Lutetian-Priabonian 
data is outside this area which prevents from testing this hypothesis (Figure 4 a,b; Supporting Table 1). Similarly, the presence of areas of decreased seasonality due to changes in the hydrological cycle cannot be confirmed because of a lack of data in these areas: although some of the data associated with a decrease in the MATR share the same latitudinal bands, none of them are directly located within a zone of MATR decrease. It might be of interest checking for additional seasonal temperature records to better trace such eventual early trends. This low fit was, to some extent, predictable since the $2 \mathrm{X}$ simulation was set ice-free and thus, does not either represent the late Eocene nor the early Oligocene (see Material and Method section). Indeed, small scale glaciations (25-35\% modern AIS) have been described already during the late Eocene, before the EOT, associated with a moderate sea-level decrease (Carter et al., 2017; Miller et al., 2020; Scher et al., 2014). Interestingly, the combination of the three forcing mechanisms also lead to a better agreement of modelled $\triangle \mathrm{MATR}$ and middle to late Eocene data, especially in coastal areas of Kamchatka, and South China (triangles, Figure 4). Although the 70$\mathrm{m}$ sea level decrease from the 2X-ICE-SL simulation is too important for the late Eocene, the better data-model agreement when both AIS and sea-level decrease are considered suggests that small ice-sheet development before the EOT may have played a significant role in driving the middle to late Eocene $\triangle$ MATR. Additional sensitivity experiments, with lower sealevel drop, may enable quantifying the sensitivity of coastal localities to before EOT smaller sea-level variations.

\subsubsection{Temperature seasonality changes through the EOT}

The use of two simulations to set up the effect of the AIS onset (with or without a drop-in sea level) is interesting to unravel the mechanisms affecting temperatures. Temperature changes resulting from AIS alone are consistent with former model studies that simulate a highly regional effect on atmospheric temperature, although the changes we observe spread more widely over the Southern Ocean and Australia (see supporting information of Hutchinson et al., 2021 for model maps). However, the decreasing seasonality zones modelled at high and mid-latitudes of the Southern Hemisphere are associated with an absence of seasonality change in the data, which often display stable vegetation and biomes from the late Eocene to the Rupelian (Hutchinson et al., 2021; Kohn et al., 2015; Nott and Owen, 1992; Pocknall, 1989; Pound and Salzmann, 2017). This apparent mismatch calls into question the capability of paleobotanical proxies to record temperature seasonality decrease in environments already characterized by low seasonality. Indeed, the decrease in the temperature seasonality is associated with a more pronounced drop in summer temperatures, which is a less limiting factor for flora distribution and thus less constrained in the fossil record than winter temperatures (Huber and Caballero, 2011).

The best representation of the temperature seasonality evolution from Priabonian to Rupelian arises when sea level drop is taken into account. This consequence of the Antarctic glaciation has global repercussions and explains part of the heterogeneity documented in the data (Pound and Salzmann, 2017). Note that our results are very dependent on the paleogeography used in the simulations. Because our Rupelian simulations are constructed from Priabonian geography with sea-level lowering, some of the paleogeographic changes that occurred between both periods are not represented, which may affect our seasonality reconstruction. The gradual northward migration of Australia is not considered; the Neotethys is gradually closed during the early Oligocene but a deep-sea passage remains present in our map, to the north of the Arabian 
https://doi.org/10.5194/cp-2021-27

Preprint. Discussion started: 1 April 2021

(c) Author(s) 2021. CC BY 4.0 License.

\section{(c) $\underset{\mathrm{BY}}{\mathrm{BV}}$}

Plate (Barrier et al., 2018). Failure to take this difference into account could lead to a misrepresentation of $\triangle$ MATR in this

area. Another source of error may come from fragmented continental areas such as seen in Europe at that time. In these zones, temperature changes recorded through the EOT are heterogeneous with paleovegetation studies suggesting medium (1.8 - 2.1 ${ }^{\circ} \mathrm{C}$; Moraweck et al., 2019; Teodoridis et Kvaček, 2015; Tosal et al., 2019) to strong (up to $8.3^{\circ} \mathrm{C}$; Tanrattana et al., 2020) MATR increase. A late intensification of seasonality in Central and Eastern Europe, related to changes in geography induced by sea level decline and not by the $p \mathrm{CO}_{2}$ lowering, is consistent with fairly stable vegetation between the middle and late Eocene (Bozukov et al., 2009; Kvaček et al., 2014; Moraweck et al., 2015). This may result from the proximity with the warm Tethys, which may have buffered the EOT cooling, as suggested by stable $\delta^{18} \mathrm{O}$ describing moderate temperature changes in this area (Kocsis et al., 2014). The heterogeneity shown in data might thus result from smaller scale paleogeographic changes through the EOT that are not represented in our simulations.

In addition, differences between our modelling results and data may also be related to the amplitude of the sea-level drop used in our simulation compared to its variability during the Rupelian. The EOT is generally described in two steps: a first event at $\sim 33.9$ Ma with both a decrease in temperature and sea level $(\sim 25 \mathrm{~m})$ and a second event, the Early Oligocene Glacial Maximum (EOGM), between approximately 33.65 and $33.15 \mathrm{Ma}$, starting after a large oxygen isotope incursion (often referred to as "Oi-1"), which is characterized by an additional $50 \mathrm{~m}$ sea-level decrease (see Hutchinson et al., 2021 for synthesis and terminology, and Miller et al., 2020). The sum of these two steps corresponds to the boundary conditions of our simulation. However, important variations of the East Antarctic Ice-Sheet have been described until the early Miocene (50-60 m sea-level equivalent; Miller et al., 2020). Directly after the EOGM phase, a decrease in ice-volume is visible between 33.15 and 32.8 Ma, before increasing again and remaining stable between 32.8 and 29 Ma (after the "Oi-1a" event; Galeotti et al., 2016). Due to the combined effects of the drop in $\mathrm{CO}_{2}$ and the development of the AIS (and the amplitude of the associated drop in sea level, $70 \mathrm{~m}$ ), the important changes in seasonality reconstructed here (2X-ICE-SL minus $3 \mathrm{X}$ ) were probably not in place throughout the Rupelian, but rather for shorter periods during the EOGM, or later between 32.8-29 Ma. Most continental paleoclimate studies do not provide the resolution to distinguish these steps. Among the data points we compiled for this study only four sites have enough temporal resolution to be linked to the EOGM phase represented by our 2X-ICE-SL simulation (Bozukov et al., 2009; Eldrett et al., 2009; Hren et al., 2013; Kohn et al., 2015; Tosal et al., 2019).

\subsection{Perspectives on environmental and biotic crisis}

460 The EOT is associated with major extinction events, of which the best known are the "Grande Coupure" in Europe and the "Mongolian Remodelling" in central Asia (Stehlin, 1909; Meng and McKenna, 1998; see Coxall and Pearson, 2007 for review). Although first recognized as a major biotic turnover for ungulates (Blondel, 2001; Stehlin, 1909), this biological crisis also affected other vertebrates, including rodents, primates, amphibians and squamates, and is also expressed by major changes in vegetation that vary regionally (e.g., Barbolini et al., 2020; Dolezych et al. in press; Eldrett et al., 2009; Marigó et al., 2014; Pound and Salzmann, 2017; Rage, 1986, 2013; Rage and Roček, 2003). These changes have been linked to (1) competitive interactions resulting from the dispersal of Asian taxa to Europe, and (2) EOT climate deterioration and 
https://doi.org/10.5194/cp-2021-27

Preprint. Discussion started: 1 April 2021

(c) Author(s) 2021. CC BY 4.0 License.

selection processes through resource and/or habitat changes (e.g. Hooker et al., 2004; Kratz and Geisler, 2010; Marigó et al., 2014; Sun et al., 2015; Zhang et al., 2012). The latter mechanism is commonly related to irreversible cooling and/or aridification at the EOT (e.g. Blondel, 2001; Sun et al., 2015; Zhang et al., 2012). Climate cooling may have significantly reduced the habitat of well spread early Eocene tropical (and paratropical) species, characterized by narrow thermal ecological niches (Hren et al., 2009; Huang et al., 2020; Jaramillo et al., 2006; Wing, 1987). Although the distribution of fauna and flora is based on a complex set of parameters, we discuss here how $\triangle$ MATR provides an additional interpretative key for understanding biotic turnover at the EOT.

While Asia and North America show comparable temperature changes, our simulations highlight significant differences in the evolution of their MATR, which increase and decrease respectively. Vegetation changes and the Mongolian Remodelling are contemporaneous to AIS growth between 32.8-29 Ma and can be compared with our 2X-ICE-SL simulation (Galeotti et al., 2016; Kraatz and Geisler, 2010; Sun et al., 2015). The MATR strengthening modelled in Asia shows that cooling was particularly strong during winter. In addition to the aridification, this more pronounced winter-cooling may have contributed to the intensity of extinctions in this area (Barbolini et al., 2020; Dupont-Nivet et al., 2007). Conversely, the decrease in

480 MATR in North America provides an explanation for the low impact of the EOT on fauna and vegetation in this area (Coxall and Pearson, 2007; Prothero and Heaton, 1996; Stucky, 1992). Despite a similar decrease of the mean annual temperature, most of the temperature drop is in summer and isn't associated with the onset of cold winters (Figure S3). We hypothesize that these patterns enabled a greater persistence of existing warm-temperate to paratropical vegetation and associated biota (Pound and Salzmann, 2017). The study of Tardif et al. (in preparation) using the same model and similar simulations (4X and $2 \mathrm{X}$-ICE) with a dynamic vegetation module shows moderate biome changes across the EOT in this area. This hypothesis is consistent with moderate vegetation changes across the EOT in areas decreasing seasonality in the Southern Hemisphere (see discussion 4.1.3).

Europe stands in an intermediate position between North America and Asia with generally weaker changes in MATR; Eastern Europe displays a slight increase in MATR, while MATR decreases in the west. Although comparable $\triangle$ MATR values could have different impacts depending on initial MATR, the types of ecosystems and their resilience, the strong consequences of moderate seasonality increase on growing season length supports the hypothesis that seasonality changes may have contributed to shaping the biodiversity evolution in Central Europe. The late development of increased seasonality zones in this area, linked to sea level drop, could explain the persistence of fairly stable vegetation during the Eocene (Kvaček et al., 2014; Hutchinson et al., 2021). Differences in the evolution of the MATR between North America, Europe and Asia support several studies suggesting different causes for EOT extinctions (Blondel, 2001; Hooker et al., 2004; Meng and McKenna 1998; Sun et al., 2015). Finally, little is known about the EOT in Africa, but the rare data available suggest stable flora and fauna in northern Africa (Hutchinson et al., 2021; Pound and Salzmann, 2017; Rasmussen et al., 1992). The significant increase in seasonality in North Africa seen in our simulations differs from the one observed in other areas, since it is linked to an increase in summer temperatures (barely no change in winter). We propose that unchanged winter 
500 temperatures might explain the apparent lack of biotic response through the EOT in North Africa., though more data are needed on this continent to better document the EOT response.

\section{Conclusion}

This study investigates the changes in temperature seasonality during the middle to late Eocene and across the EOT. The combined effects of $p \mathrm{CO}_{2}$ drop, AIS formation and sea-level decrease impact the seasonality in the right direction when compared to the reconstruction of the late Eocene to early Oligocene changes in MATR. The decrease in $p \mathrm{CO}_{2}$ leads to a marked strengthening of seasonality at high northern latitudes, which may have started earlier than the EOT, during the late Eocene. The formation of the AIS and the resulting sea-level drop lead to both an intensification and an extension of increasing seasonality areas. When all three parameters are combined, a statistically significant correlation between data and modeled MATR evolution throughout the EOT is reached. Accounting for sea level changes associated with Antarctic

510 freeze-up appears to be the most important parameter to explain the heterogeneity of $\triangle \mathrm{MATR}$ across EOT. A seasonality increase is also visible in middle to late Eocene localities, which may reflect earlier sea level changes associated with the precursors of the Antarctic ice sheet. A discrepancy between data and model is present for MATR estimates across the EOT, with less marked seasonality changes in the model. This is mainly due to areas where a decrease in seasonality is predicted by the model while the vegetation proxies show stable vegetation. We hypothesize that this discrepancy can be explained by

515 a low capacity of vegetation to register decreases in summer temperatures compared to winter temperatures.

Reconstructing changes in MATR brings additional constraints on the environmental pressure applied on land between the middle Eocene and the early Oligocene. The different mechanisms described here likely explain the heterogeneity in seasonality changes found in data across the greenhouse-icehouse transition, and provide insights into the diversity of continental paleoenvironments. The map of $\triangle$ MATR reconstructed here may provide new elements to better understand

520 major extinction events at the EOT. This study only focused on the evolution of temperature seasonality; the variability of other seasonality parameters, including rainfall seasonality, would also be worth investigating to better picture the evolution of terrestrial climates and biodiversity through the EOT. In addition, further work using higher resolution Rupelian paleogeography and regional models would be of great interest to better reconstruct temperature seasonality changes, especially in highly fragmented land areas such as Europe during the Eocene.

\section{Code availability}

LMDZ, XIOS, NEMO and ORCHIDEE are released under the terms of the CeCILL license. OASISMCT is released under the terms of the Lesser GNU General Public License (LGPL). IPSL-CM5A2 code is publicly available through svn, with the following command lines:

svn co 
https://doi.org/10.5194/cp-2021-27

Preprint. Discussion started: 1 April 2021

(c) Author(s) 2021. CC BY 4.0 License.

(c) (i)

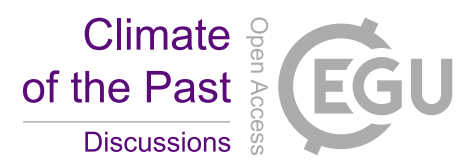

http://forge.ipsl.jussieu.fr/igcmg/svn/modipsl/branches/publications/IPSLCM5A2.1_11192019 (last access: 16 February

530 2021, IPSL Climate Modelling Centre, 2021a) modipsl cd modips1/util;./model IPSLCM5A2.1

The mod.def file provides information regarding the different revisions used, namely

- NEMOGCMbranchnemo_v3_6_STABLErevision666-XIOS2branchs/xios-2.5revision1763

- IOIPSL/srcsvntags/v2_2_2

- $\quad$ LMDZ5branches/IPSLCM5A2.1rev3591

- branches/publications/ORCHIDEE_IPSLCM5A2.1.r5307rev6336-OASIS3-MCT2.0_branch(rev4775IPSLserver)

The login/password combination requested for the first use to download the ORCHIDEE component is anonymous/anonymous. We recommend referring to the project website http://forge.ipsl.jussieu.fr/igcmg doc/wiki/Doc/Config/IPSLCM5A2 (last access: 16 February 2021, IPSL Climate Modelling Centre, 2021b) for a proper installation and compilation of the environment.

\section{Data availability}

The key climatological outputs of the simulations are stored in the PANGAEA database (data are currently under review and may be sent to reviewers upon request).

\section{Author contribution}

YD, AT and JBL conducted the modelling experiments. AT compiled proxy-data, analyzed the model results, generated

545 figures and tables, and drafted the manuscript. AT, YD, DT and JBL discussed the paleoclimate results. LK contributed to the paleobotanical context, and AL and GDN to the paleogeographic and geological context. All authors have provided critical feedback and contributed to the final manuscript.

\section{Competing interests}

The authors declare that they have no conflict of interest.

\section{Acknowledgment}

We thank the CEA/CCRT for providing access to the HPC resources of TGCC under the allocation 2018-A0030102212, and 2019-A0050102212 made by GENCI. We acknowledge the support of the ERC MAGIC under Grant 649081. The authors acknowledge Cheng-Sen Li for sharing a translation of the reference Budantsev (1997). We acknowledge use of Ferret (ferret.pmel.noaa.gov/Ferret/) and RStudio software (rstudio.com) for analysis and figures in this paper. 
https://doi.org/10.5194/cp-2021-27

Preprint. Discussion started: 1 April 2021

(c) Author(s) 2021. CC BY 4.0 License.

\section{References}

Abbot, D. S., and Tziperman, E. (2008). A high-latitude convective cloud feedback and equable climates. Quarterly Journal of the Royal Meteorological Society, 134(630), 165-185.https://doi.org/10.1002/qj.211

Allen, M. R., and Ingram, W. J. (2002). Constraints on future changes in climate and the hydrologic cycle. Nature, 419(6903), 228-232. https://doi.org/10.1038/nature01092

560 Aumont, O., Ethé, C., Tagliabue, A., Bopp, L., and Gehlen, M. (2015). PISCES-v2: An ocean biogeochemical model for carbon and ecosystem studies. Geoscientific Model Development, 8(8), 2465-2513. https://doi.org/10.5194/gmd-8-2465$\underline{2015}$

Baatsen, M., von der Heydt, A. S., Huber, M., Kliphuis, M. A., Bijl, P. K., Sluijs, A., and Dijkstra, H. A. (2020). The middle to late Eocene greenhouse climate modelled using the CESM 1.0.5. Climate of the Past, 16(6), 2573-2597. https://doi.org/10.5194/cp-16-2573-2020

Barbolini, N., Woutersen, A., Dupont-Nivet, G., Silvestro, D., Tardif, D., Coster, P. M. C., Meijer, N., Chang, C., Zhang, H.X., Licht, A., Rydin, C., Koutsodendris, A., Han, F., Rohrmann, A., Liu, X.-J., Zhang, Y., Donnadieu, Y., Fluteau, F., Ladant, J.-B., ... Hoorn, C. (2020). Cenozoic evolution of the steppe-desert biome in Central Asia. Science Advances, 6(41), eabb8227. https://doi.org/10.1126/sciadv.abb8227

570 Barrier, E., Vrielynck, B., Brouillet, J.-F., and Brunet, M.-F. (2018). Paleotectonic Reconstruction of the Central Tethyan Realm. Tectonono-Sedimentary-Palinspastic maps from Late Permian to Pliocene. CCGM/CGMW, Paris, http://www.ccgm.org.

Bishop, P., and Bamber, R. K. (1985). Silicified wood of Early Miocene Nothofagus, Acacia and Myrtaceae (aff. Eucalyptus B) from the upper Lachlan valley, New South Wales. Alcheringa: An Australasian Journal of Palaeontology, 9(3), 221-228. https://doi.org/10.1080/03115518508618969

Blondel, C. (2001). The Eocene-Oligocene ungulates from Western Europe and their environment. Palaeogeography, Palaeoclimatology, Palaeoecology, 168(1), 125-139. https://doi.org/10.1016/S0031-0182(00)00252-2

Bozukov, V., Utescher, T., and Ivanov, D. (2009). Late Eocene to early Miocene climate and vegetation of Bulgaria. Review of Palaeobotany and Palynology, 153(3-4), 360-374. https://doi.org/10.1016/j.revpalbo.2008.10.005

580 Budantsev, L.Y., 1997. Late Eocene flora of western Kamchatka. Proceedings of Komarov Botanical Institute, Russian Academy of Sciences. 19, pp. 1-115 (in Russian).

Caballero, R., and Huber, M. (2013). State-dependent climate sensitivity in past warm climates and its implications for future climate projections. Proceedings of the National Academy of Sciences, 110(35), 14162-14167. https://doi.org/10.1073/pnas.1303365110

585 Carmichael, M. J., Lunt, D. J., Huber, M., Heinemann, M., Kiehl, J., LeGrande, A., Loptson, C. A., Roberts, C. D., Sagoo, N., Shields, C., Valdes, P. J., Winguth, A., Winguth, C., and Pancost, R. D. (2016). A model-model and data-model comparison for the early Eocene hydrological cycle. Climate of the Past, 12(2), 455-481. https://doi.org/10.5194/cp-12-455$\underline{2016}$

Carter, A., Riley, T. R., Hillenbrand, C.-D., and Rittner, M. (2017). Widespread Antarctic glaciation during the Late Eocene. Earth and Planetary Science Letters, 458, 49-57. https://doi.org/10.1016/j.eps1.2016.10.045 
https://doi.org/10.5194/cp-2021-27

Preprint. Discussion started: 1 April 2021

(c) Author(s) 2021. CC BY 4.0 License.

\section{(c) (i)}

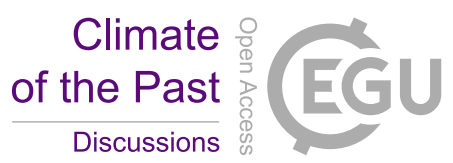

Coxall, H. K., and Pearson, P. N. (2007). The Eocene-Oligocene Transition. In M. Williams, A. M. Haywood, F. J. Gregory, and D. N. Schmidt (Eds.), Deep-Time Perspectives on Climate Change: Marrying the Signal from Computer Models and Biological Proxies (First, pp. 351-387). The Geological Society of London on behalf of The Micropalaeontological Society. https://doi.org/10.1144/TMS002.16

595 Coxall, H. K., Wilson, P. A., Pälike, H., Lear, C. H., and Backman, J. (2005). Rapid stepwise onset of Antarctic glaciation and deeper calcite compensation in the Pacific Ocean. Nature, 433(7021), 53-57.https://doi.org/10.1038/nature03135

Dufresne, J.-L., Foujols, M.-A., Denvil, S., Caubel, A., Marti, O., Aumont, O., Balkanski, Y., Bekki, S., Bellenger, H., Benshila, R., Bony, S., Bopp, L., Braconnot, P., Brockmann, P., Cadule, P., Cheruy, F., Codron, F., Cozic, A., Cugnet, D., ... Vuichard, N. (2013). Climate change projections using the IPSL-CM5 Earth System Model: From CMIP3 to CMIP5. Climate Dynamics, 40(9-10), 2123-2165. https://doi.org/10.1007/s00382-012-1636-1

Dupont-Nivet, G., Krijgsman, W., Langereis, C. G., Abels, H. A., Dai, S., and Fang, X. (2007). Tibetan plateau aridification linked to global cooling at the Eocene-Oligocene transition. Nature, 445(7128), 635-638. https://doi.org/10.1038/nature05516

Eldrett, J. S., Greenwood, D. R., Harding, I. C., and Huber, M. (2009). Increased seasonality through the Eocene to Oligocene transition in northern high latitudes. Nature, 459(7249), 969.https://doi.org/10.1038/nature08069

Fichefet, T., and Maqueda, M. A. M. (1997). Sensitivity of a global sea ice model to the treatment of ice thermodynamics and dynamics. Journal of Geophysical Research: Oceans, 102(C6), 12609-12646. https://doi.org/10.1029/97JC00480

Foster, G. L., Royer, D. L., and Lunt, D. J. (2017). Future climate forcing potentially without precedent in the last 420 million years. Nature Communications, 8(1), 14845. https://doi.org/10.1038/ncomms14845

610 Galeotti, S., DeConto, R., Naish, T., Stocchi, P., Florindo, F., Pagani, M., Barrett, P., Bohaty, S. M., Lanci, L., Pollard, D., Sandroni, S., Talarico, F. M., and Zachos, J. C. (2016). Antarctic Ice Sheet variability across the Eocene-Oligocene boundary climate transition. Science, 352(6281), 76-80. https://doi.org/10.1126/science.aab0669

Goldner, A., Herold, N., and Huber, M. (2014). Antarctic glaciation caused ocean circulation changes at the EoceneOligocene transition. Nature, 511(7511), 574-577. https://doi.org/10.1038/nature13597

615 Goldner, A., Huber, M., and Caballero, R. (2013). Does Antarctic glaciation cool the world? Climate of the Past, 9(1), 173189. https://doi.org/10.5194/cp-9-173-2013

Gough, D. O. (1981). Solar interior structure and luminosity variations. Solar Physics, 74(1), 21-34. https://doi.org/10.1007/BF00151270

Grein, M., Oehm, C., Konrad, W., Utescher, T., Kunzmann, L., and Roth-Nebelsick, A. (2013). Atmospheric CO2 from the 620 late Oligocene to early Miocene based on photosynthesis data and fossil leaf characteristics. Palaeogeography, Palaeoclimatology, Palaeoecology, 374, 41-51. https://doi.org/10.1016/j.palaeo.2012.12.025

Grimes, S. T., Hooker, J. J., Collinson, M. E., and Mattey, D. P. (2005). Summer temperatures of late Eocene to early Oligocene freshwaters. Geology, 33(3), 189-192. https://doi.org/10.1130/G21019.1

Grimm, G. W., and Potts, A. J. (2016). Fallacies and fantasies: The theoretical underpinnings of the Coexistence Approach

for palaeoclimate reconstruction. Climate of the Past, 12(3), 611-622.https://doi.org/10.5194/cp-12-611-2016

Held, I. M., and Soden, B. J. (2006). Robust Responses of the Hydrological Cycle to Global Warming. Journal of Climate, 19(21), 5686-5699. https://doi.org/10.1175/JCLI3990.1 
https://doi.org/10.5194/cp-2021-27

Preprint. Discussion started: 1 April 2021

(c) Author(s) 2021. CC BY 4.0 License.

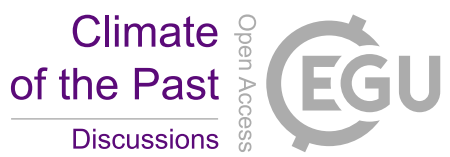

Hooker, J. J., Collinson, M. E., and Sille, N. P. (2004). Eocene-Oligocene mammalian faunal turnover in the Hampshire Basin, UK: Calibration to the global time scale and the major cooling event. Journal of the Geological Society, 161(2), 161172. https://doi.org/10.1144/0016-764903-091

Hourdin, F., Grandpeix, J.-Y., Rio, C., Bony, S., Jam, A., Cheruy, F., Rochetin, N., Fairhead, L., Idelkadi, A., Musat, I., Dufresne, J.-L., Lahellec, A., Lefebvre, M.-P., and Roehrig, R. (2013). LMDZ5B: The atmospheric component of the IPSL climate model with revisited parameterizations for clouds and convection. Climate Dynamics, 40(9-10), $2193-2222$. https://doi.org/10.1007/s00382-012-1343-y

635 Hren, M. T., Sheldon, N. D., Grimes, S. T., Collinson, M. E., Hooker, J. J., Bugler, M., and Lohmann, K. C. (2013). Terrestrial cooling in Northern Europe during the Eocene-Oligocene transition. Proceedings of the National Academy of Sciences, 110(19), 7562-7567.https://doi.org/10.1073/pnas.1210930110

Huang, H., Morley, R., Licht, A., Dupont-Nivet, G., Grímsson, F., Zetter, R., Westerweel, J., Win, Z., Wa Aung, D., and Hoorn, C. (2020). Eocene palms from central Myanmar in a South-East Asian and global perspective: Evidence from the palynological record. Botanical Journal of the Linnean Society.https://doi.org/10.1093/botlinnean/boaa038

Huber, M., and Caballero, R. (2011). The early Eocene equable climate problem revisited. Climate of the Past, 7(2), 603633. https://doi.org/10.5194/cp-7-603-2011

Hutchinson, D. K., Coxall, H. K., Lunt, D. J., Steinthorsdottir, M., de Boer, A. M., Baatsen, M., von der Heydt, A., Huber, M., Kennedy-Asser, A. T., Kunzmann, L., Ladant, J.-B., Lear, C. H., Moraweck, K., Pearson, P. N., Piga, E., Pound, M. J.,

645 Salzmann, U., Scher, H. D., Sijp, W. P., ... Zhang, Z. (2021). The Eocene-Oligocene transition: A review of marine and terrestrial proxy data, models and model-data comparisons. Climate of the Past, 17(1), 269-315. https://doi.org/10.5194/cp$17-269-2021$

Hutchinson, D. K., Coxall, H. K., O'Regan, M., Nilsson, J., Caballero, R., and de Boer, A. M. (2019). Arctic closure as a trigger for Atlantic overturning at the Eocene-Oligocene Transition. Nature Communications, 10(1), 3797. https://doi.org/10.1038/s41467-019-11828-Z

Hutchinson, D. K., de Boer, A. M., Coxall, H. K., Caballero, R., Nilsson, J., and Baatsen, M. (2018). Climate sensitivity and meridional overturning circulation in the late Eocene using GFDL CM2.1. Climate of the Past, 14(6), 789-810. https://doi.org/10.5194/cp-14-789-2018

IPSL Climate Modeling Centre: IPSL-CM5A-VLR branche IPSLCM5A2.1_11192019, available at: http://forge.ipsl.jussieu.fr/igcmg/svn/modipsl/branches/publications/IPSLCM5A2.1_11192019, last access: 16 February 2021a.

IPSL Climate Modeling Centre: IPSL climate models documentation, available at: http://forge.ipsl.jussieu.fr/igcmg_doc/wiki/Doc/Config/IPSLCM5A2, last access: 16 February 2021b.

Ivany, L. C., Patterson, W. P., and Lohmann, K. C. (2000). Cooler winters as a possible cause of mass extinctions at the Eocene/Oligocene boundary. Nature, 407(6806), 887-890. https://doi.org/10.1038/35038044

Jaramillo, C., Rueda, M. J., and Mora, G. (2006). Cenozoic Plant Diversity in the Neotropics. Science, 311(5769), 18931896. https://doi.org/10.1126/science.1121380

Joomun, S. C., Hooker, J. J., and Collinson, M. E. (2010). Changes in dental wear of Plagiolophus minor (Mammalia: Perissodactyla) across the Eocene-Oligocene transition. Journal of Vertebrate Paleontology, 30(2), 563-576. https://doi.org/10.1080/02724631003618124 
https://doi.org/10.5194/cp-2021-27

Preprint. Discussion started: 1 April 2021

(c) Author(s) 2021. CC BY 4.0 License.

(c) (i)

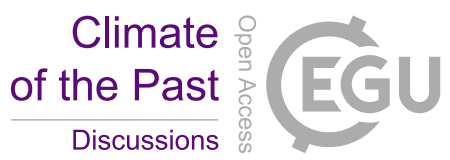

Katz, M. E., Miller, K. G., Wright, J. D., Wade, B. S., Browning, J. V., Cramer, B. S., and Rosenthal, Y. (2008). Stepwise transition from the Eocene greenhouse to the Oligocene icehouse. Nature Geoscience, 1(5), 329-334. https://doi.org/10.1038/ngeo179

Kayseri-Özer, M. S. (2013). Spatial distribution of climatic conditions from the Middle Eocene to Late Miocene based on

670 palynoflora in Central, Eastern and Western Anatolia. Geodinamica Acta, 26(1-2), $122-157$. https://doi.org/10.1080/09853111.2013.877237

Kennedy, A. T., Farnsworth, A., Lunt, D. J., Lear, C. H., and Markwick, P. J. (2015). Atmospheric and oceanic impacts of Antarctic glaciation across the Eocene-Oligocene transition. Philosophical Transactions of the Royal Society A: Mathematical, Physical and Engineering Sciences, 373(2054), 20140419. https://doi.org/10.1098/rsta.2014.0419

675 Kennedy-Asser, A. T., Lunt, D. J., Farnsworth, A., and Valdes, P. J. (2019). Assessing Mechanisms and Uncertainty in Modeled Climatic Change at the Eocene-Oligocene Transition. Paleoceanography and Paleoclimatology, 34(1), 16-34. https://doi.org/10.1029/2018PA003380

Kennedy-Asser, Alan T., Lunt, D. J., Valdes, P. J., Ladant, J.-B., Frieling, J., and Lauretano, V. (2020). Changes in the highlatitude Southern Hemisphere through the Eocene-Oligocene transition: A model-data comparison. Climate of the Past,

680 16(2), 555-573. https://doi.org/10.5194/cp-16-555-2020

Kocsis, L., Ozsvárt, P., Becker, D., Ziegler, R., Scherler, L., and Codrea, V. (2014). Orogeny forced terrestrial climate variation during the late Eocene-early Oligocene in Europe. Geology, 42(8), 727-730. https://doi.org/10.1130/G35673.1

Kohn, M. J., Strömberg, C. A. E., Madden, R. H., Dunn, R. E., Evans, S., Palacios, A., and Carlini, A. A. (2015). Quasistatic Eocene-Oligocene climate in Patagonia promotes slow faunal evolution and mid-Cenozoic global cooling.

Palaeogeography, Palaeoclimatology, Palaeoecology, 435, 24-37.https://doi.org/10.1016/j.palaeo.2015.05.028

Kraatz, B. P., and Geisler, J. H. (2010). Eocene-Oligocene transition in Central Asia and its effects on mammalian evolution. Geology, 38(2), 111-114. https://doi.org/10.1130/G30619.1

Krinner, G., Viovy, N., de Noblet-Ducoudré, N., Ogée, J., Polcher, J., Friedlingstein, P., Ciais, P., Sitch, S., and Prentice, I. C. (2005). A dynamic global vegetation model for studies of the coupled atmosphere-biosphere system. Global Biogeochemical Cycles, 19(1). https://doi.org/10.1029/2003GB002199

Kunzmann, L., Kvacek, Z., Teodoridis, V., Müller, C., and Moraweck, K. (2016). Vegetation dynamics of riparian forest in central Europe during the late Eocene. Palaeontographica Abteilung B, 295, 69-89. https://doi.org/10.1127/palb/295/2016/69

Kvaček, Z. (2010). Forest flora and vegetation of the European early Palaeogene - a review. Bulletin of Geosciences, 85(1), 63-76. https://doi.org/10.3140/bull.geosci.1146

695 Kvaček, Z., Teodoridis, V., Mach, K., Přikryl, T., and Dvořák, Z. (2014). Tracing the Eocene-Oligocene transition: A case study from North Bohemia. Bulletin of Geosciences, 89(1), 21-66.https://doi.org/10.3140/bull.geosci.1411

Ladant, J.-B., Donnadieu, Y., and Dumas, C. (2014a). Links between CO2, glaciation and water flow: Reconciling the Cenozoic history of the Antarctic Circumpolar Current. Climate of the Past, 10(6), 1957-1966. https://doi.org/10.5194/cp10-1957-2014

700 Ladant, J.-B., Donnadieu, Y., Lefebvre, V., and Dumas, C. (2014b). The respective role of atmospheric carbon dioxide and orbital parameters on ice sheet evolution at the Eocene-Oligocene transition: Ice sheet evolution at the EOT. Paleoceanography, 29(8), 810-823. https://doi.org/10.1002/2013PA002593 
https://doi.org/10.5194/cp-2021-27

Preprint. Discussion started: 1 April 2021

(c) Author(s) 2021. CC BY 4.0 License.

(c) (i)

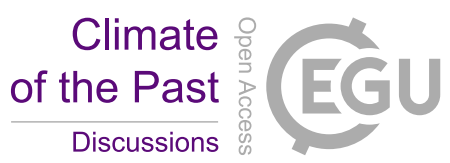

Lear, C. H., Bailey, T. R., Pearson, P. N., Coxall, H. K., and Rosenthal, Y. (2008). Cooling and ice growth across the Eocene-Oligocene transition. Geology, 36(3), 251.https://doi.org/10.1130/G24584A.1

705 Li, S., Xing, Y., Valdes, P. J., Huang, Y., Su, T., Farnsworth, A., Lunt, D. J., Tang, H., Kennedy, A. T., and Zhou, Z. (2018). Oligocene climate signals and forcings in Eurasia revealed by plant macrofossil and modelling results. Gondwana Research, 61, 115-127. https://doi.org/10.1016/j.gr.2018.04.015

Li, Y., Smith, T., Svetlana, P., Yang, J., Jin, J.-H., and Li, C.-S. (2014). Paleobiogeography of the lotus plant (Nelumbonaceae: Nelumbo) and its bearing on the paleoclimatic changes. Palaeogeography, Palaeoclimatology,

710 Palaeoecology, 399, 284-293. https://doi.org/10.1016/j.palaeo.2014.01.022

Lunt, D. J., Bragg, F., Chan, W.-L., Hutchinson, D. K., Ladant, J.-B., Niezgodzki, I., Steinig, S., Zhang, Z., Zhu, J., AbeOuchi, A., de Boer, A. M., Coxall, H. K., Donnadieu, Y., Knorr, G., Langebroek, P. M., Lohmann, G., Poulsen, C. J., Sepulchre, P., Tierney, J., ... Otto-Bliesner, B. L. (2020). DeepMIP: Model intercomparison of early Eocene climatic optimum (EECO) large-scale climate features and comparison with proxy data. Climate of the Past Discussions.

715 https://doi.org/10.5194/cp-2019-149

Lunt, D. J., Farnsworth, A., Loptson, C., Foster, G. L., Markwick, P., O’Brien, C. L., Pancost, R. D., Robinson, S. A., and Wrobel, N. (2016). Palaeogeographic controls on climate and proxy interpretation. Climate of the Past, 12(5), 1181-1198. https://doi.org/10.5194/cp-12-1181-2016

Madec, G. (2008). NEMO ocean engine (Note Du Pôle de Modélisation de l'Institut Pierre-Simon Laplace).

720 Marigó, J., Susanna, I., Minwer-Barakat, R., Madurell-Malapeira, J., Moyà-Solà, S., Casanovas-Vilar, I., Robles, J. M., and Alba, D. M. (2014). The primate fossil record in the Iberian Peninsula. Journal of Iberian Geology, 40(1), 157-166. https://doi.org/10.5209/rev JIGE.2014.v40.n1.44094

Matthews, K. J., Maloney, K. T., Zahirovic, S., Williams, S. E., Seton, M., and Müller, R. D. (2016). Global plate boundary evolution and kinematics since the late Paleozoic. Global and Planetary Change, 146, 226-250. https://doi.org/10.1016/j.gloplacha.2016.10.002

Meng, J., and McKenna, M. C. (1998). Faunal turnovers of Palaeogene mammals from the Mongolian Plateau. Nature, 394(6691), 364-367.https://doi.org/10.1038/28603

Miller, K. G., Browning, J. V., Schmelz, W. J., Kopp, R. E., Mountain, G. S., and Wright, J. D. (2020). Cenozoic sea-level and cryospheric evolution from deep-sea geochemical and continental margin records. Science Advances, 6(20), eaaz1346. https://doi.org/10.1126/sciadv.aaz1346

Moraweck, K., Grein, M., Konrad, W., Kvaček, J., Kova-Eder, J., Neinhuis, C., Traiser, C., and Kunzmann, L. (2019). Leaf traits of long-ranging Paleogene species and their relationship with depositional facies, climate and atmospheric $\mathrm{CO} 2$ level. Palaeontographica Abteilung B, 298(4-6), 93-172.https://doi.org/10.1127/palb/2019/0062

Mosbrugger, V., Utescher, T., and Dilcher, D. L. (2005). Cenozoic continental climatic evolution of Central Europe.

Proceedings of the National Academy of Sciences, 102(42), 14964-14969. https://doi.org/10.1073/pnas.0505267102

Mosbrugger, Volker, and Utescher, T. (1997). The coexistence approach-A method for quantitative reconstructions of Tertiary terrestrial palaeoclimate data using plant fossils. Palaeogeography, Palaeoclimatology, Palaeoecology, 134(1-4), 61-86. https://doi.org/10.1016/S0031-0182(96)00154-X 
https://doi.org/10.5194/cp-2021-27

Preprint. Discussion started: 1 April 2021

(c) Author(s) 2021. CC BY 4.0 License.

Nott, J. F., and Owen, J. A. K. (1992). An Oligocene palynoflora from the middle Shoalhaven catchment N.S.W. and the

740 Tertiary evolution of flora and climate in the southeast Australian highlands. Palaeogeography, Palaeoclimatology, Palaeoecology, 95(1-2), 135-151.https://doi.org/10.1016/0031-0182(92)90169-6

PALAEOSENS Project Members. (2012). Making sense of palaeoclimate sensitivity. Nature, 491(7426), 683-691. https://doi.org/10.1038/nature11574

Pocknall, D. T. (1989). Late Eocene to early Miocene vegetation and climate history of New Zealand. Journal of the Royal

Society of New Zealand, 19(1), 1-18.https://doi.org/10.1080/03036758.1989.10426451

Pound, M. J., and Salzmann, U. (2017). Heterogeneity in global vegetation and terrestrial climate change during the late Eocene to early Oligocene transition. Scientific Reports, 7(1), 43386. https://doi.org/10.1038/srep43386

Prothero, D. R., and Heaton, T. H. (1996). Faunal stability during the Early Oligocene climatic crash. Palaeogeography, Palaeoclimatology, Palaeoecology, 127(1), 257-283. https://doi.org/10.1016/S0031-0182(96)00099-5

750 Quan, C., Liu, Y.-S. (Christopher), and Utescher, T. (2012). Paleogene temperature gradient, seasonal variation and climate evolution of northeast China. Palaeogeography, Palaeoclimatology, Palaeoecology, 313-314, 150-161. https://doi.org/10.1016/j.palaeo.2011.10.016

R Core Team (2020). R: A language and environment for statistical computing. R Foundation for Statistical Computing, Vienna, Austria. URL https://www.r-project.org/.

755 Rage, J.-C. (1986). The Amphibians and Reptiles at the Eocene-Oligocene Transition in Western Europe: An Outline of the Faunal Alterations. In Ch. Pomerol and I. Premoli-Silva (Eds.), Developments in Palaeontology and Stratigraphy (Vol. 9, pp. 309-310). Elsevier. https://doi.org/10.1016/S0920-5446(08)70135-3

Rage, J.-C. (2013). Mesozoic and Cenozoic squamates of Europe. Palaeobiodiversity and Palaeoenvironments, 93(4), 517534. https://doi.org/10.1007/s12549-013-0124-X

760 Rasmussen, D. T., Brown, T. M., and Simons, E. L. (1992). The Eocene-Oligocene Transition in continental Africa. In D. R. Prothero and W. A. Berggren (Eds.), Eocene-Oligocene Climatic and Biotic Evolution (pp. 548-567). Princeton University Press.

Roček, Z., and Rage, J.-C. (2003). Evolution of anuran assemblages in the Tertiary and Quaternary of Europe, in the context of palaeoclimate and palaeogeography. Amphibia-Reptilia, 24(2), 133-167.https://doi.org/10.1163/156853803322390408

765 Sagoo, N., Valdes, P., Flecker, R., and Gregoire, L. J. (2013). The Early Eocene equable climate problem: Can perturbations of climate model parameters identify possible solutions? Philosophical Transactions of the Royal Society A: Mathematical, Physical and Engineering Sciences, 371(2001), 20130123. https://doi.org/10.1098/rsta.2013.0123

Scher, H. D., Bohaty, S. M., Smith, B. W., and Munn, G. H. (2014). Isotopic interrogation of a suspected late Eocene glaciation: Hidden glaciation revealed in the Eocene. Paleoceanography, 29(6), 628-644.

770 https://doi.org/10.1002/2014PA002648

Sepulchre, P., Caubel, A., Ladant, J.-B., Bopp, L., Boucher, O., Braconnot, P., Brockmann, P., Cozic, A., Donnadieu, Y., Dufresne, J.-L., Estella-Perez, V., Ethé, C., Fluteau, F., Foujols, M.-A., Gastineau, G., Ghattas, J., Hauglustaine, D., Hourdin, F., Kageyama, M., ... Tardif, D. (2020). IPSL-CM5A2 - an Earth system model designed for multi-millennial climate simulations. Geoscientific Model Development, 13(7), 3011-3053. https://doi.org/10.5194/gmd-13-3011-2020

775 Stehlin, H. G. (1909). Remarques sur les faunules de Mammifères des couches éocènes et oligocènes du Bassin de Paris. Société Géologique de France. 
https://doi.org/10.5194/cp-2021-27

Preprint. Discussion started: 1 April 2021

(c) Author(s) 2021. CC BY 4.0 License.

(c) (i)

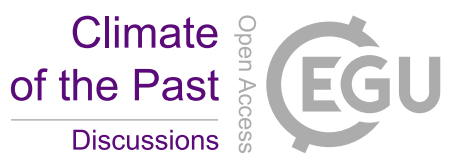

Stucky, R. K. (1992). In Eocene-Oligocene Climatic and Biotic Evolution (pp. 464-493). Princeton University Press. https://www.degruyter.com/princetonup/view/book/9781400862924/10.1515/9781400862924.464.xml

Sun, J., Ni, X., Bi, S., Wu, W., Ye, J., Meng, J., and Windley, B. F. (2015). Synchronous turnover of flora, fauna and climate

at the Eocene-Oligocene Boundary in Asia. Scientific Reports, 4(1), 7463. https://doi.org/10.1038/srep07463

Tanrattana, M., Boura, A., Jacques, F. M. B., Villier, L., Fournier, F., Enguehard, A., Cardonnet, S., Voland, G., Garcia, A., Chaouch, S., and Franceschi, D. D. (2020). Climatic evolution in Western Europe during the Cenozoic: Insights from historical collections using leaf physiognomy. Geodiversitas, 42(11), 151-174. https://doi.org/10.5252/geodiversitas2020v42a11

785 Tardif, D., Fluteau, F., Donnadieu, Y., Hir, G. L., Ladant, J.-B., Sepulchre, P., Licht, A., Poblete, F., and Dupont-Nivet, G. (2020). The origin of Asian monsoons: A modelling perspective. Climate of the Past, 16(3), 847-865. https://doi.org/10.5194/cp-16-847-2020

Tardif, D., Toumoulin, A., Fluteau, F., Donnadieu, Y., le Hir, G., Barbolini, N., Licht, A., Ladant, J.-B., Sepulchre, P., Viovy, N., Hoorn, C. and Dupont-Nivet, G. (Submitted). Orbital variation as a major driver of climate and biome distribution during late Eocene to early Oligocene times.

Teodoridis, V., \& Kvaček, Z. (2015). Palaeoenvironmental evaluation of Cainozoic plant assemblages from the Bohemian Massif (Czech Republic) and adjacent Germany. Bulletin of Geosciences, 695-720. https://doi.org/10.3140/bull.geosci.1553

Tosal, A., Valero, L., Sanjuan, J., and Martín-Closas, C. (2019). Influence of short-and long-term climatic cycles on floristic change across the Eocene-Oligocene boundary in the Ebro Basin (Catalonia, Spain). Comptes Rendus Palevol, 18(8), 925-

795 947.https://doi.org/10.1016/j.crpv.2019.10.003

Toumoulin, A., Donnadieu, Y., Ladant, J. -B., Batenburg, S. J., Poblete, F., and Dupont-Nivet, G. (2020). Quantifying the effect of the Drake Passage opening on the Eocene Ocean. Paleoceanography and Paleoclimatology. https://doi.org/10.1029/2020PA003889

Utescher, T., Bruch, A. A., Erdei, B., François, L., Ivanov, D., Jacques, F. M. B., Kern, A. K., Liu, Y.-S. (C.), Mosbrugger,

800 V., and Spicer, R. A. (2014). The Coexistence Approach-Theoretical background and practical considerations of using plant fossils for climate quantification. Palaeogeography, Palaeoclimatology, Palaeoecology, 410, 58-73. https://doi.org/10.1016/j.palaeo.2014.05.031

Utescher, Torsten, Bondarenko, O. V., and Mosbrugger, V. (2015). The Cenozoic Cooling - continental signals from the Atlantic and Pacific side of Eurasia. Earth and Planetary Science Letters, 415, 121-133. 805 https://doi.org/10.1016/j.eps1.2015.01.019

Wade, B. S., Houben, A. J. P., Quaijtaal, W., Schouten, S., Rosenthal, Y., Miller, K. G., Katz, M. E., Wright, J. D., and Brinkhuis, H. (2012). Multiproxy record of abrupt sea-surface cooling across the Eocene-Oligocene transition in the Gulf of Mexico. Geology, 40(2), 159-162. https://doi.org/10.1130/G32577.1

Wing, S. L. (1987). Eocene and Oligocene Floras and Vegetation of the Rocky Mountains. Annals of the Missouri Botanical 810 Garden, 74(4), 748-784. JSTOR.https://doi.org/10.2307/2399449

Wolfe, J. A. (1992). 21. Climatic, Floristic, and Vegetational Changes near the Eocene/Oligocene Boundary in North America. In D. R. Prothero and W. A. Berggren (Eds.), Eocene-Oligocene Climatic and Biotic Evolution (pp. 421-436). Princeton University Press. https://doi.org/10.1515/9781400862924.421 
https://doi.org/10.5194/cp-2021-27

Preprint. Discussion started: 1 April 2021

(c) Author(s) 2021. CC BY 4.0 License.

(c) (i)

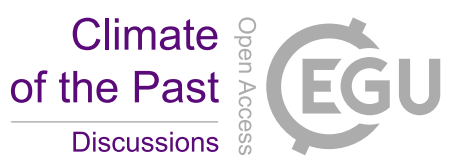

Wolfe, J. A. (1993). A method of obtaining climatic parameters from leaf assemblages (p. 71). U.S. Geological Survey 815 Bulletin 2040.https://doi.org/10.3133/b2040

Wolfe, J. A. (1994). Tertiary climatic changes at middle latitudes of western North America. Palaeogeography, Palaeoclimatology, Palaeoecology, 108(3), 195-205.https://doi.org/10.1016/0031-0182(94)90233-X

Yang, J., Spicer, R. A., Spicer, T. E. V., and Li, C.-S. (2011). 'CLAMP Online': A new web-based palaeoclimate tool and its application to the terrestrial Paleogene and Neogene of North America. Palaeobiodiversity and Palaeoenvironments, 91(3),

820 163-183. https://doi.org/10.1007/s12549-011-0056-2

Zachos, J., Pagani, M., Sloan, L. C., Thomas, E., and Billups, K. (2001). Trends, Rhythms, and Aberrations in Global Climate 65 Ma to Present. Science, 292(5517), 686-693. https://doi.org/10.1126/science.1059412

Zanazzi, A., Judd, E., Fletcher, A., Bryant, H., and Kohn, M. J. (2015). Eocene-Oligocene latitudinal climate gradients in North America inferred from stable isotope ratios in perissodactyl tooth enamel. Palaeogeography, Palaeoclimatology,

825 Palaeoecology, 417, 561-568. https://doi.org/10.1016/j.palaeo.2014.10.024

Zanazzi, A., Kohn, M. J., MacFadden, B. J., and Terry, D. O. (2007). Large temperature drop across the Eocene-Oligocene transition in central North America. Nature, 445(7128), 639-642. https://doi.org/10.1038/nature05551

Zhang, R., Kravchinsky, V. A., and Yue, L. (2012). Link between global cooling and mammalian transformation across the Eocene-Oligocene boundary in the continental interior of Asia. International Journal of Earth Sciences, 101(8), 2193-2200. https://doi.org/10.1007/s00531-012-0776-1

Zhu, J., Poulsen, C. J., and Tierney, J. E. (2019). Simulation of Eocene extreme warmth and high climate sensitivity through cloud feedbacks. Science Advances, 5(9), eaax1874. https://doi.org/10.1126/sciadv.aax1874 